Elsevier required licence: (c) 2019. This manuscript version is made available under the CC-BY-NC-ND 4.0 license http://creativecommons.org/licenses/by-nc-nd/4.0/

The definitive publisher version is available online at https://doi.org/10.1016/j.jclepro.2018.12.049 


\title{
Only Non-Energy Benefits from the Adoption of Energy Efficiency Measures? A Novel Framework
}

\author{
Enrico Cagno a, Davide Moschetta a, Andrea Trianni ${ }^{b, *}$ \\ a Politecnico di Milano, Dept. Management, Economics and Industrial Engineering \\ Piazza Leonardo da Vinci 32 - 20133 Milan (Italy) \\ ${ }^{b}$ University of Technology Sydney, School of Systems, Management and Leadership, Faculty of \\ Engineering and IT, 81 Broadway - 2007 Ultimo, NSW (Australia)
}

“corresponding author: andrea.trianni@uts.edu.au

\section{Highlights}

- Review of existing studies over Non-Energy Benefits

- Novel framework characterizing impact of energy efficiency measures

- Benefits as well as Losses should be considered by industrial decision-makers

- Beside service phase, major relevance of implementation phase highlighted

- EEMs should be characterized also by impacts on the operations

\begin{abstract}
Industrial energy efficiency has been widely recognized as a major contributor to the reduction of greenhouse gases emissions and improvement of industrial competitiveness. Nevertheless, a broad set of studies have pointed out the existence of barriers limiting the adoption of promising Energy Efficiency Measures (EEMs). Recently, scholars have shown the relevance of the so-called "nonenergy benefits" (NEBs) coming from the adoption of EEMs for overcoming those barriers. Still, the existence of such benefits has been pointed out from specific studies and manuals for practitioners, but an overall framework describing them in terms of savings and benefits, as well as technical and management implications, is missing yet. Moreover, a considerable part of the scholars and of the practitioners just focuses on the identification and definition of the positive benefits deriving from these measures after they have been completely adopted, thus neglecting to describe the full set of both positive and negative effects occurring also during the implementation phase. Thus, starting from a literature review of scientific as well as practitioners' studies, we have proposed a novel framework and characterization of the relevant items to be considered by an industrial decisionmaker when deciding whether to adopt an EEM considering both the implementation and service
\end{abstract}


phases. Hence, by taking this perspective, we have tested and validated the framework and the characterisation in a two-step process: firstly, considering a set of EEMs well diffused and adopted in industry; secondly, investigating benefits and losses in ad-hoc selected manufacturing companies. Finally, considerations and implications are drawn from the preliminary validation and suggestion for further research are proposed, for both industrial decision-making as well as policy-making purposes.

\section{Keywords}

Energy Efficiency; Non-Energy Benefit (NEB); Framework; Characterisation; Energy Efficiency Measure (EEM).

\section{Introduction}

Despite increased energy efficiency is being widely recognized as utmost importance for industrial competitiveness and climate change mitigation (IEA 2017), the adoption rate of Energy Efficiency Measures (EEMs) is still quite low (Anderson and Newell, 2004; Cagno and Trianni, 2012), showing the existence of a huge "energy efficiency gap" (Backlund et al., 2012) that is yet to be filled. The discussion over the reasons behind such low implementation rate is quite mature, with both many theoretical as well as empirical contributions (for recent reviews of studies on barriers to energy efficiency, please refer to, e.g. (Brunke et al., 2014; Cagno and Trianni, 2014, Trianni et al., 2016; UNECE, 2017). Despite the huge efforts on barriers, scholars and industry have so far paid little attention to increase the knowledge on how to overcome such barriers (Thollander et al., 2007). Recently, some literature contributions have tried to model drivers for energy efficiency (Thollander et al., 2013; Trianni et al., 2017). Among others, scholars point out that a better knowledge of the so-called Non-Energy Benefits (NEBs) could potentially modify the perception of the decision-maker about the profitability of adopting EEMs (Heffner and Campbell, 2011). In this regard, some examples in literature can be found (e.g., Worrell et al., 2003, or more recently Nehler et al., 2018a), also with discussion over possible implications between NEBs and other policy mechanisms (Nehler et al., 2018b), but so far literature has not widely highlighted and discussed the consequences (either positive or negative) deriving from the adoption of EEMs over its entire lifetime, mainly limiting to the positive effects after putting in service an EEM. Nevertheless, it is clear in the day-by-day decisions that an industrial decision-maker's perspective needs to consider the broader set of operative implications (again, either positive or negative) when both implementing and then exploiting an EEM, also by looking at possible either positive or negative synergies with other activities (Cagno et al., 2018). A structured framework thoroughly describing and classifying the relevant items (and related implications) to be considered by an industrial decision-maker when deciding whether to adopt an EEM could help reduce market barriers, especially regarding imperfect information and adverse selection (Sorrell et al., 2000; Brown, 2001). For this reason, in our study, we aim to offer a 
contribution to address this research gap. This represents a crucial step that could pave the way for further research aimed at quantifying the impacts.

The remainder of the paper is as follows: we discuss our literature background in Section 2, presenting and focusing on the main contributions. Section 3 is devoted to the presentation of the framework, trying to characterize the impacts both positive and negative during its implementation and service phases, stemming from the adoption of an EEM, through a series of selected features and attributes. In Section 4 we have conducted a validation of the framework through literature data and case studies in selected industries, whereas in Section 5 we draw considerations and implications for both industrial decision-making and policy-making purposes, as well as acknowledging our study limitations, concluding with suggestions for further research.

\section{Literature Background}

As a rationale, in the following, the key contributions to the academic debated over benefits from the adoption of EEMs are presented, followed by a discussion of the current research gaps that led to the development of the novel framework. We have focused our literature background exclusively in the industrial sector.

The concept that the adoption of an EEM could bring more than energy savings is relatively young in literature. Mills and Rosenfeld (1996) have studied the role of "additional benefits", focused on EEMs for buildings. In their work, authors pointed out mainly seven categories, as follows: improved indoor environment, noise reduction, labour and time savings, improved process control, increased amenity or convenience, water savings and waste minimization, and direct and indirect economic benefits from downsizing or elimination of equipment. The authors note that these non-energy benefits play a key role in consumer decision-making. Boyd and Pang (2000) have offered additional contributions in quantifying the NEBs, by showing that productivity differences between plants were statistically significant in explaining differences in plant energy intensity. Pye and McKane (2000) and Lilly and Pearson (1999) have instead conducted several case studies in companies to point out the need to account for all the monetary savings that a business will realize from energy efficiency projects. More recently, Mills et al. (2008) have discussed opportunities and benefits from enhanced energy management for high-tech industries.

Stronger attempt to more deeply characterize and systematically monetize productivity benefits has been given by Worrell et al. (2003). The authors, on the one hand, have categorized benefits rearranging those proposed by Mills and Rosenfeld into six categories, as follows: i) waste reduction; ii) emissions reduction; iii) operation and maintenance; iv) production; v) working environment; and vi) other. On the other hand, they have adopted the conservation supply curves (CSCs) as a means to evaluate the profitability of EEMs. Interestingly, authors, have acknowledged that productivity benefits cannot be always easily quantified in monetary terms. Based on the approach proposed by Worrell et al. (2003) and Laitner et al. (2001), Finman and Laitner (2001) have investigated the 
impacts of NEBs by analysing 77 different literature case studies. Further, Lung et al. (2005) have reviewed the results from 81 energy efficiency projects in US industrial facilities using the same approach.

More recently the discussion has delved, on the one hand, beyond economic benefits (Schweitzer and Tonn, 2003), on the other, widely beyond the shop floor benefits. For what concerns the first, interestingly, Bunse et al. (2011) have defined three macro-categories of benefits based on a triple bottom line (TBL) perspective of sustainability: economic, environmental and societal. For each of these classes, a list of benefits has been defined. Finster and Hernke (2014) make leverage on the consideration of gaining a competitive advantage from the implementation of the EEMs. Seven domains have been identified, namely: i) markets and products; ii) reputation; iii) risk; iv) human resources; v) sourcing; vi) collaboration; and vii) strategic direction. In addition, for each of them, there is the proposal of different benefits. Regarding the latter, Tonn and Peretz (2007), through the discussion of several programs in the US, point out state-level benefits from the adoption of EEMs. Similarly, Kuzuki et al. (2010) and Ikaga et al. (2011) pointed out additional benefits at the regional level from adopting EEMs. IEA (2012) has conducted a wider analysis of the socio-economic outcomes arising from an EEM, beyond energy savings. Additionally, IEA (2014) has published a broad report on the multiple benefits of energy efficiency, from individuals to macro-economic impacts. Further, Skumatz (2015) has discussed that NEBs have multiple uses, from supporting marketing, to help optimize program design and delivery, up to training the different stakeholders involved in the supply chain of EEMs.

Rasmussen (2017) has conducted a systematic literature review over the terms "ancillary benefits", "co-benefits" and "non-energy benefits", also sketching two interesting attributes that should be looked when considering NEBs, i.e. their quantifiability (from low to high), as well as time frame, i.e. weather NEBs can be perceived in the short or long term. The two attributes have been interestingly considered by Nehler and Rasmussen (2016) to evaluate NEBs for energy efficiency investments in Swedish industry. Moreover, Nehler (2018) has linked EEMs with NEBs, by considering industrial compressed air systems: more in detail, the author has distinguished between NEBs for energy efficiency improvements in general (i.e. that can be appreciated at firm level), from those at energyusing process (e.g. compressed air), from those of a specific EEM (e.g., sealing of leaks). Taking inspiration from Nehler (2018), a list of specific NEBs has been used to investigate barriers, drivers and NEBs in compressed air systems by Nehler et al. (2018a). The existence of additional benefits for EEMs in compressed air systems has been also found by Doyle and Cosgrove (2018).

If the discussion over benefits was pretty well-established, only a few studies have addressed the possible negative impacts from the adoption of energy efficiency measures. Indeed, in an earlier contribution, Piette \& Normand (1996) have attempted to consider in the investment analysis also the so-called "deficiencies", intended as operational problems existing in the plant before the EEM completion. Such deficiencies could be directly related to the EEM, indirectly related to the EEM - 
as in case of a deficiency that could have been found even without the implementation of the measure considered - and, finally, unrelated to EEM. Skumatz and Gardner (2005), in their study on commercial and industrial energy efficiency programs, have instead referred to "net positive and negative" impacts that must be incorporated in the decision over EEMs. Beside the key contributions presented above, Table 1 summarizes our literature background, reporting both whether studies have focused on just the service phase of an EEM or also on the implementation phase, as well as distinguishing between the type of impact of the impact, i.e. either positive or negative, as also pointed out by previous literature (Cagno et al., 2016).

$$
<<\text { Table 1 >> }
$$

By looking at previous studies, we can conclude that the vast majority of contributions is focused almost exclusively on the benefits with a positive impact arising in the service phase, i.e. after the adoption of the measure has been completed, thus neglecting either the negative impacts (as shown by Skumatz e Gardner, 2005) or those occurring during the implementation phase (Piette and Nordman 1996).

However, according to the perspective of an industrial decision maker, it is important to perform a frank and complete analysis of the EEMs, including the effects of each phase in the previously mentioned description as well as possible negative impacts (here called "losses") both in the implementation as well as in the service phase.

Moreover, previous studies have offered several interesting perspectives on the benefits, describing in which area - within a company - a benefit could be perceived (see, e.g., Worrell et al., 2003 on production, or operations \& maintenance). Furthermore, Elliott et al. (1997) interestingly suggest that "project" benefits may exist beyond energy savings, thus pointing out that some benefits are not dependent on the energy-flow variation, rather on the implementation of the EEM itself. Additionally, IEA $(2012,2014)$ has pointed out benefits from the adoption of EEMs may be either direct or indirect. In particular, they are defined as direct if they are a consequence of the having implemented an EEM, while they are indirect if they can be experienced as consequences (or evolutions) of the direct benefits. All such features represent valuable attributes of the possible impact to be considered when undertaking the decision to adopt an EEM. But, from a decision-maker's perspective, several additional features seem to be needed in order to encompass the broader spectrum of impacts when adopting and EEM.

In the next section, we present the novel framework for the impacts related to the adoption of an EEM, along with their characterization.

\section{A novel framework characterizing the impacts}


The literature background offered many contributions to the discussion by suggesting, although in many cases not explicitly, the existence of some features and attributes characterising impacts from the adoption of EEMs. The novel framework indeed tries to encompass previous literature in a holistic approach, so to offer industrial decision-makers a holistic perspective on the impacts helping them take decisions over EEMs, and, in the meanwhile, to provide them with a comprehensive map of all the possible impacts.

\subsection{Main features}

Stemming from the analysis of previous literature, we describe the four main features of the impacts, that are deemed to be able, on the one side, to help the industrial decision-makers understand the main characteristics of the impacts stemming from the adoption of an EEM, and, on the other, to categorise all such impacts (Figure 1; last column), thus improving the awareness of decision-makers about their existence.

Origin. By taking inspiration from Pye and McKane (2000), two possible origins have been identified for the impacts: the measure itself (i.e. the activity of implementing the EEM) and the variation of the energy flow consequent to the adoption of the EEM. On the one hand, when referable to the measure itself, an impact can be attributed to the sequence of activities required for accomplishing an EEM (e.g., improved equipment availability). On the other hand, an impact can be limited exclusively to the energy flow reduction (e.g., reduction of $\mathrm{CO}_{2}$ emissions due to saved energy). This feature is designed to support industrial decision-makers highlight also relevant impacts stemming from the adoption of an EEM, beyond energy-saving itself.

Relationship with the energy flow. Following on from IEA (2012), we distinguish between direct and indirect impacts, basing on the possibilities of achieving its evaluation directly through the energy flow variation. When implementing an EEM, the reduction of the emissions due to saved energy consumption, as it specifically stems from the reduced energy flow, it is indeed a direct benefit. Rather, e.g. a reduction in the workload of people managing the energy contracts into a company is an indirect benefit due to an energy flow variation (reduction). Therefore, it is apparent that all measure-originated impacts are indirect, being not strictly dependant on the energy flow variation. On the other hand, the variation of the energy flow can bring both direct and indirect impacts. This feature is designed to help industrial decision-makers pay more attention on the existence of possible indirect impacts, often disregarded.

Achievement of the impact. It is defined as the opportunity of obtaining an effect itself with or without any further investment. Hence, an impact is considered as primary if obtained thanks to the accomplishment of the EEM. In the other case, the impact is deemed as secondary, i.e. it can be obtained only through further combined actions. This is the case, e.g., of EEMs related to smart 
metering: the adoption itself does not lead to any energy saving, unless jointly done with, e.g., the investment in a campaign to systematically monitor energy consumption and further actions such as, e.g., equipment retrofitting. Indeed, so far literature has discussed primary impacts, that, being closer in time with respect to the decision-making process, they are usually taken into account. Nevertheless, it is important to point out that secondary impacts (either positive or negative) with respect to the adoption of an EEM may arise (usually later on after the decision of adopting an EEM has been taken). This feature is designed to help industrial decision-makers look at EEM in a longterm perspective, thus going beyond impacts that can be immediately obtained, thus paying more attention to the future and/or combined EEMs.

Phase. As preliminarily discussed in the literature background, two phases in the EEM lifetime should be included: the implementation and service phase (Piette and Norman, 1996). By implementation phase, we consider the time window including the decommissioning of the existing (supposed nonefficient) equipment, being followed by the installation, testing and the start-up of the new equipment or, when dealing with practices, the time to effectively implement a new and more energy-efficient one. The service phase rather refers to the time in which the EEM operates, after being put in place, bringing energy savings. By combining the two phases, the whole lifetime of the measure is obtained. It is important to operate the distinction between the two phases as, e.g., despite the service life of higher energy-efficient motors can be quite long, in a thorough evaluation of undertaking this EEM, production disruption could be a crucial impact occurring in the implementation phase. This feature is designed to help industrial decision-makers look at the whole lifetime when evaluating the adoption of an EEM. Indeed, as literature previous showed, too little attention is being paid to distinguishing between implementation and service phase: an EEM may be adopted looking exclusively at the service phase benefits (thus not sufficiently considering the losses in the implementation phase as, e.g., production disruption). Alternatively, production disruption is often considered as an important issue hindering the adoption of an EEM, without sufficiently considering the following service phase.

Taking into consideration the above-described features, the impacts stemming from the adoption of an EEM can be allocated into a category (Figure 1; last column). It is crucial, taking inspiration from Skumatz and Gardner (2005), to define whether the impact has a positive or negative effect on the firm. This leads to the distinction between positive impacts, identified hereafter as Benefits (e.g., reduction of noise), from negative ones, defined as Losses (e.g., production disruption). For this reason, regarding the aforementioned primary impacts, we clearly distinguished between:

- Energy Benefits (EBs, direct);

- Service Non-Energy Benefits (or simply, Non-Energy Benefits, NEBs, indirect);

- Service Non-Energy Losses (or simply, Non-Energy Losses, NELs, indirect).

EBs encompass all direct flow-originated benefits after putting in service an EEM. NEBs accounts for all the positive indirect benefits that arise because of an EEM, while NELs include all the indirect 
impacts with a negative effect on the organization. Similarly, we should distinguish primary benefits from losses in the implementation phase, thus obtaining the Implementation NEBs and Implementation NELs. Further, to encompass the many implications and synergies stemming from EEMs' implementation, we have defined Implementation Positive (or Negative) Synergies. Concerning secondary impacts, we have pointed out the existence of Secondary Benefits (and the Secondary Losses), i.e. those arising during the service phase of the measure, deriving from the combination with other actions. Figure 1 summarizes the detailed rationale behind the novel framework, whilst Figure 2 shows that the new framework, by distinguishing between benefits and losses, as well as implementation and service phase (as previous authors note, see e.g., Cagno et al., 2016), can better describe impacts thus going much beyond "Service Non-Energy Benefits", offering enhanced knowledge to decision-makers.

$$
\begin{aligned}
& <<\text { Figure } 1>> \\
& <<\text { Figure } 2>>
\end{aligned}
$$

\subsection{Additional attributes}

As several authors note (e.g., Worrell et al., 2003), a mere identification of the impacts may not be sufficient to offer enough valuable support to a decision-maker in adopting an EEM when evaluating its impacts. Therefore, a further effort in classifying and characterizing them is needed, fully describing the many important additional attributes allowing for a proper decision-making phase over an EEM.

In particular, our literature research has allowed to understand several areas to which the attributes may refer. Nature and beneficiary represents a first area widely explored by previous research, e.g. pointing out the importance of considering that multiple benefits may be of different "subtle and complex nature" (Mills and Rosenfeld, 1996). The capability of a benefit to be experienced (Persistence) (Heffner and Campbell, 2011) has been deemed relevant as well. Furthermore, the Temporal aspect is a third area widely discussed by previous authors (e.g., Pye and McKane, 2000). The Perception from several stakeholders is pointed out as an important issue to be considered when evaluating non-energy benefits (IEA, 2014). Finally, several authors refer to Cash flow generation either explicitly (e.g., Lazar and Colburn, 2013) or implicitly (e.g., Worrell et al., 2003 through conservation supply curves) as a crucial element for a holistic evaluation of non-energy benefits. For this reason, following previous literature, each identified impact of the EEM has been described through fourteen attributes specifically defined, and divided into the aforementioned five categories. In the following, we present the detailed set of attributes for each category.

Nature and beneficiary. Taking inspiration from previous literature (e.g., Worrell et al., 2003), it is important to highlight which is the area of the company affected, as well as who, within the area, is 
going to be affected (extension) (IEA, 2014). Additionally, as previous authors note (e.g., Bunse et al. 2011; Piette and Nordman 1996), a decision-maker could be interested in understanding which is the nature of the impact, such as e.g., production, maintenance, work environment conditions.

Persistence. Previous research noted that an impact may substantially differ according to changes in the production system (resilience) (Shirali et al., 2015). Moreover, an impact can be appreciated only after putting in service an EEM or stemming from the implementation of the EEM (duration) (Heffner and Campbell 2011). Additionally, it is important to understand whether continuous actions are needed to maintain a certain benefit (maintainability) (De Leon et al., 2012). Finally, it is crucial to consider whether the intensity of an impact is stable over time or tends to decrease, e.g., during the service phase (stability).

Temporal aspect. This aspect has been widely recognised by literature as quite relevant (Mills and Rosenfeld, 1996; Pye and McKane, 2000). More in detail, it is important to highlight when a possible peak in the impact may occur, as well as how frequently it is needed to act so to maintain the impact (e.g. a benefit) (frequency of exploitation).

Perception. This category aims at pointing out the possible effect that an impact may have internally (i.e., within a company) or externally. With greater detail, the attributes aim at understanding the perception (about the impact) by different stakeholders (following IEA, 2014), namely customers, suppliers. operators, and local community.

Cash flow generation. Taking inspiration from previous literature (IEA, 2014), this category is important since an impact (e.g. a benefit) with implications in terms of cash flow generation beyond energy savings (e.g. cash inflow increase or cash outflow reduction) may influence the decisionmaking process over an EEM.

To conclude, the additional attributes have been detailed and a qualitative evaluation scale (taking inspiration from e.g., Nehler et al., 2018) is proposed (Table 2).

$<<$ Table 2>>

\section{Validation of the proposed framework}

We have performed a preliminary validation of the proposed framework, on the one hand, to assess it in terms of completeness and usability, on the other, to test its capability of defining additional knowledge about EEMs that would support the decision-making phase. Completeness has to be 
intended as a set of properties, considering whether: $i$ ) the framework is able to cover all possible impacts; ii) the characterization provides a complete description of the impacts' features interesting for the industrial decision-maker; iii) there is no significant overlapping among different attributes/ features proposed within the characterization; and iv) the level of detail provided by each feature is homogenous. Usability rather aims at testing the ease of use by the industrial decision-maker and the modularity of the characterization proposed, both in terms of information available and priority in pointing out the impacts and their features. Finally, in the usability we have conducted a specific investigation regarding the evaluation scales proposed for each feature, defining whether the parameters included could be easily assessed by an end-user.

The validation phase has been accomplished in two steps: in the first phase, we have analysed a list of EEMs identified in the academic and industrial literature, whilst in the second one we have performed ad-hoc selected interviews within Italian manufacturing companies. Because of the different nature of these two steps, the targets of each phase are slightly different. The literature validation has focused on testing the completeness and the level of detail of the information to be provided in each part. The empirical phase has rather focused on the assessment of completeness and usability when the end-user has to evaluate the adoption of an EEM. In addition, this step has been exploited to provide indications about the capability of defining additional knowledge of the EEMs that would support the decision-making phase.

\subsection{Literature validation}

The seven EEMs considered in this phase have been chosen looking at previous literature (Trianni et al. 2014), taking into account measures most diffused and adopted in the industry with available literature describing the EEMs and the indication of the full range of impacts deriving from their adoption. The EEMs analysed are presented in Table 3. The selection has been conducted according to the following criteria (taking inspiration from Trianni et al., 2014; Anderson and Newell, 2004; Cagno and Trianni, 2012):

- EEMs belonging to the most diffused cross-cutting technologies in industries (i.e. motor, compressed air, lighting and HVAC systems);

- EEMs with proven impact either in the production conditions (core process), on the operations (including Operations and Maintenance), or on the working conditions;

- EEMs with different implementation rates;

- EEMs with different corporate involvement (thus low in case of a people involved, or wide in case of having the whole company involved); and

- EEMs with a different likelihood of success.

$<<$ Table 3>> 
Considering the existing literature exploited for the individuation of the EEMs above reported, we defined the impacts belonging to each of the categories defined by the framework. For sake of brevity, in Table 4 we limit to report the final results stemming from the adoption of the framework. Indeed, all the information available was used and classified. In the end, the framework proved to be able to easily embrace and classify all the information found in the literature related to the EEM considered. Interestingly, we were able to refer all the information reported in the detailed description of the EEM, easily distinguishing for primary impacts not only between benefits and losses, but also between service and implementation phase. Furthermore, pointing out the existence of possible secondary effects did not represent a major issue. In the following, for sake of brevity, only two cases in the following boxes (Box 1 and 2) are presented with further detail. In particular, Box 1 and 2 contain relevant literature information regarding two selected EEMs ("Size electric motors for peak operating efficiency" and "Improve air circulation with destratification fans/other methods"), showing the capability of the framework to gather literature information and structure it in a way to best support decision-makers over EEM.

$<<$ Table 4>>

\section{Box 1: Size electric motors for peak operating efficiency}

Motors can be effectively replaced mainly in two situations (ETSU, 1998): in case of a relevant motor technical failure; or when a motor is working most of the time out of its best-operating conditions. making substitution economically viable. The substitution of an electric motor with a more efficient one does not usually bring large variations of the length, the fixings and the height of the shaft, except for a few cases (but such differences are usually negligible) (ETSU, 1998). Considering the service phase, as service benefit, higher efficient motors can be manufactured so that a better thermal insulation can be obtained, thus reducing heat dissipations (ETSU, 1998). Furthermore, other service benefits partially related to that are the improvement of the conditions for the operators working nearby and the reduction of the load for the air conditioning system thanks to the reduced facility heating loads (Worrell, et al., 2010). Additionally, as service benefits, the use of a more efficient and better-sized electric motor implies a longer life for bearing and insulation, a reduction of the vibrations and a higher reliability of the equipment installed (Worrell, et al., 2010), (Wulfinghoff, 1999), as well as the improved protection of the motor, intended as better protection settings and fuse rating (ETSU, 1998). Proper motor sizing can also largely reduce the load and, consequently, limit the losses of efficiency and the risk of failure for improper functioning (USDOE, 2014), (Wulfinghoff, 1999). A major issue in relation to the use of a properly sized motor relates to the starting torque provided by the motor itself. The more efficient (and, usually, smaller) motors have, indeed, a lower starting torque than the previously installed ones. But, this translates into an issue in the starting phase (ETSU, 1998), thus representing a service loss. In addition, there is the need 
for a proper gearbox so to reach maximum efficiency possible; however, this requires for additional sizing and inconveniences to the production, especially in relation to mechatronic applications (Roos, et al., 2006). By looking at the implementation phase, the substitution of the electric motor implies losses as the interruption of the production/service supply, and a possible modification in the layout (ETSU, 1998), in case of sensible variation of size. But, on the other hand, the EEM allows the inspection of the conditions of the entire system and of the elements connected with the motor substituted that offers further opportunities for improving the overall efficiency of the motor system (implementation benefit).

\section{Box 2: Improve air circulation with destratification fans/other methods}

This EEMs consists of the installation of ventilation or ceiling fans, allowing for a reduction in the stratification of the air inside the working areas interested by the EEM. The major service benefits perceived by the operators are the increased circulation of the cold air in summer and of the warm air in winter, improving the overall working conditions of the workers (Worrell, et al., 2010). This measure, not involving particular technical issues, impacts on the overall production system and the operators. Several service benefits in the overall production system can be experienced: the reduced load on the air heating system thanks to the improved air circulation (Worrell, et al., 2010) and the reduction of the cooling load (Balaras, et al., 2003). In addition, as previous authors note (Worrell, et al., 2010), a reduction of the space required can be achieved. This happens because properly designed ceiling fans allow reducing the power required, reducing motors' size, and improving the working environment conditions (Wulfinghoff, 1999; Balaras, et al., 2003). By looking at the operators, several service benefits can be appreciated. Thanks to the increased control of the temperature achievable, there is a lower noise emitted in the working environment, an improved monitoring of the HVAC system and, consequently, an improvement of the environmental conditions (Wulfinghoff, 1999). In addition, avoiding stratification brings to a reduced risk for the equipment (e.g. coil freezing) and allows to prevent damages at ducts during freezing weather. Finally, the impacts due to the EEM include the uniformity of environmental conditions, thanks to a reduction of the stratification coupled with an extended thermal comfort zone (Balaras, et al., 2003). As Wulfinghoff (1999) note, the service benefits are increased when the destratification fans are coupled with an economizer cycle thanks to the effects on the air speed, with further improvements on the environmental conditions (secondary benefits). But, it is important to note that the implementation of such EEM could require a variation of the layout, thus representing an important implementation loss to be considered in the decision-making phase.

\subsection{Empirical validation}

In the second phase, seven Italian manufacturing companies have been selected. Interviewees i.e. people knowledgeable of energy efficiency and operations management issues and responsible 
for energy efficiency investments - have been asked to use and comment over the model developed referring to the latest EEMs the company considered for adoption. A total of 14 interviews has been conducted: indeed, in several cases, we had the chance to interview multiple managers, so to receive multiple and different feedbacks that helped us further refine the attributes. Additionally, by collecting multiple evidence on the same company, we were able to analyse multiple perspectives on EEMs and therefore evaluate the existence of multiple benefits and losses.

The interview was structured with a first discussion about the framework followed by a second part where the framework has been employed. The first part regards the single features exploited during the design of the framework, in order to establish whether they were of real interest from the company's perspective and interviewees' capability in identifying, distinguishing and classify the different types of benefits and losses. This first part of the interview was conducted with the energy manager, when available, or the person knowledgeable of energy issues for the visited site and the operations/plant manager and lasted between forty-five minutes to one hour.

The second phase aims to evaluate the potential of the framework in enlarging the focus on the impacts of each EEM accomplished in the recent past from the company, highlighting the capability for describing of EEMs' impacts, discovering if issues arise during the use. This second part of the interview was conducted the same people as above, with the addition of the responsible for the design and implementation (in case, they were two people) of the EEM (and, other company management if available), and lasted between thirty minutes to one hour and a half for each company analysed.

As claimed by previous research, for the exploratory purpose of this preliminary validation, being interested in the theoretical generalizability rather than on the statistical one, a sample size from six to ten companies is considered as adequate (Eisenhardt, 1989; Pagell and Wu, 2009). The selection of the companies has been accomplished considering different characteristics as size, industrial sector, energy intensity, availability of environmental certifications and existence of an energy manager. Characteristics of companies selected are presented in Table 5. The size of the enterprises has been included because of the relationship of the number of operators with the internal organisation: the higher the number of operators, the more complex the internal organisation is, with the possibility to devote a higher attention toward the investments to be adopted (Trianni and Cagno, 2012). The sector has been included to preliminarily explore whether the framework could be applied in different contexts. Each sector presented has been defined according to the International Standard Industrial Classification of all Economic Activities (ISIC). The energy intensity is important, since it provides the relevance of the energy expenses with respect to the turnover of each company: the higher the energy intensity, the higher should be the attention paid toward energy topics (Rohdin and Thollander, 2006), similarly for what concerns the existence of environmental certifications and a higher attention for the environmental issues. Finally, we asked for the presence of an energy manager mainly for two reasons: on the one hand, a greater attention towards the cost 
reduction is expected; on the other hand, for some companies an energy manager is mandatory. Table 6 reports the results from the validation as well as the main comments collected during the interviews.

$$
\begin{aligned}
& <<\text { Table 5>> } \\
& <<\text { Table 6>> }
\end{aligned}
$$

The interviews allowed to gather useful comments on the framework as well as suggestions for specific attributes. In particular, Company A appreciated the approach, noting that the characterization and the framework brought to the identification of new NEBs, not taken into account in the decision-making phase. Additionally, the attention towards the external impacts through a structured description of the EEMs emerged as particularly useful. In other cases (Company B), by applying the framework to a set of EEMs evaluated, the company slightly changed its perspective regarding decision-making. In fact, impacts on the production or work environment emerged but were unexpected; impacts (in particular losses) were not considered in the decision-making phase, thus increasing the awareness of decision-makers regarding the effective impacts stemming from the adoption of an EEM. Company $\mathrm{C}$ has noted the focus towards an operations management perspective, thus proving the framework to be able to provide an indication of those impacts of interest for the management. Company $D$ confirmed the capability of the framework to more effectively map the knowledge regarding impacts, so to identify and highlight some so far disregarded, Also Company E confirmed this judgment, plus added that some impacts have been incorrectly forecasted. In particular, thanks to the analysis provided, the manager has pointed out that further investments would be accomplished for the adoption of skylights. Similar considerations have been drawn also for Company F. Finally, Company G, beside a very positive judgment regarding the overall structure, particularly appreciated the list of attributes to characterise EEMs, especially when making the distinction between implementation and service phase.

In short, during the empirical validation, managers evaluated the framework to be complete and usable in general terms, being able to easily encompass and clearly classify and distinguish all the available information, also allowing to point out impacts not previously considered. Moreover, the characterization was deemed to provide additional knowledge of the EEMs in supporting the decision-making phase, in particular by a deeper look to the specific impacts. Attributes have been in general considered as relevant. In a few cases, as reported in Table 6, just for what concerns the usability, some managers pointed out the need to customize the evaluation scale according to their specific context. In the following boxes, for sake of brevity, only two cases are presented in detail. In particular, Box 3 and 4, contain more detailed information regarding two companies (respectively Company $\mathrm{C}$ and $\mathrm{E}$ ) where we validated and discussed our framework. In the boxes we report a 
general overview of the company (together with a few figures over energy consumption and issues), followed by a discussion of the main findings emerged during the interviews.

\section{Box 3: Company C}

The company produces grey cast iron with a specialization in household applications and automotive sector, aluminium die-casting with a focus on automotive components and, finally, it is possible to find the magnet wire division exploiting aluminium and, most of all, copper. The company has 515 employees, with an annual turnover of approximately 155 million $€$. Energy expenditures represent about $6 \%$ of the turnover, thus the firm can be considered energy intensive (Rohdin and Thollander, 2006). With greater detail, the electric energy consumption is around $75 \mathrm{GWh}$ /year, whilst the natural gas consumption is approximately of 4.6 million $\mathrm{Sm}^{3}$. Finally, 10,800 ton/year of coke for cast iron production are used. The UNI EN ISO 14001:2004 is the only environmental certification. The company seems to show a relevant attention towards the environmental aspects related to the production. This attention is strengthened from the presence of some detection points nearby the plant, in order to continuously measure the emissions of the plant itself, maintaining proper conditions for the local community. Considering this and the current Italian regulation, an internal Energy Manager responsible for the production plant itself is mandatory. The interview has been conducted with the industrial manager of the copper division, the Total Quality Management manager, the Energy Manager and the Finance and administration manager. The interview, that lasted slightly more than two hours, has been structured in two phases: the first has brought to the judgement of the framework and its analysis, with the aim of discovering possible issues about the features and attributes included as well as the evaluation scales, while in the second part some EEMs are proposed and analysed through the framework itself. Regarding the first, the framework has been evaluated overall as complete and useful. Among the EEMs analysed with the collaboration of company's Energy Manager, we have interestingly analysed the substitution of two old furnaces for aluminium casting previously installed with another one with higher efficiency, who took place a few months before the interview. The new equipment is designed not only for being more efficient during aluminium ingots' casting, but also to be automatically controlled.

In this case, the focus is on the production impacts that arise because of the EEMs accomplished. By applying the framework, the Energy Manager recognized that, when undertaking the decision, other possible impacts were neglected. By discussing over the framework with respect to that specific EEM, the Energy Manager realized that the installation of new and efficient equipment was not able to only reduce energy expenditures (energy benefit) and increase production performance (service benefit), but, in particular, after putting in place the EEM, the company observed an increased estate value. This capability of analysing the EEMs with a higher level of precision, thus pointing out previously unobserved impacts, has been considered from the Energy Manager a crucial advantage of the developed framework and characterization. 
In addition to the above, during the interview, some feedbacks have been received concerning the classification of the perceived impacts. The features proposed are deemed to be satisfactory for the description of the impacts; in two cases the evaluation scales have been customized with further options.

Combining the characterization of the impacts and their classification, we could note a strong relationship among the analysis accomplished and the perspective of the company. This is suggested by considering that similar impacts have been perceived from the Energy Manager with almost the same description through the option made available during the interview. In this case, it is possible to state that the model herein proposed would be a strong improvement for the company because it would fasten the process and, at the same time, would allow enlarging the perspective on EEMs, having a more detailed and complete description of the impacts.

\section{Box 4: Company E}

This small company (37 employees) operates in the North-East of Italy in manufacturing furniture for offices, with annual turnover of approximately 5.3 million $€$ and an annual energy expenditure of about 47,000 €/year (194.74 MWh/year of electric energy, purchased for $36,500 € /$ year, and additional $10,500 € /$ year required for fuel oil and natural gas, substantially used for the conditioning of the internal environment and heat required from the process), thus with a ratio between energy expenditures and turnover of about $0.88 \%$ (non-energy intensive). The company is not UNI EN ISO 14001:2004 certified, even if the standards proposed from the same regulation are claimed to be respected by the company. Considering, finally, the actual energy consumption, an internal Energy Manager is not mandatory. The interview took place with two people, respectively the company owner (and plant directory) and the maintenance manager, and lasted about two hours. For what concerns the validation of the features and attributes of the framework, respondents appreciated the approach and considered it of large interest to properly describe the impacts stemming from the adoption of an EEM. With regard to investigated EEMs, interestingly insights came from the installation of skylights in the production departments. After the renewal of the roof insulation, the company has undergone a second measure consisting of the installation of skylights in a portion of the roof, so to exploit natural daylight. Several improvements have been appreciated by the company, despite a precise quantification of energy savings still needs to be done (but a saving of around $18 \%$ of electric energy for lighting purposes was estimated). By applying the framework, the company has also pointed out that, differently from what done in the decision-making phase, an unexpected beneficial effect on the operators' visual comfort could be observed. Furthermore, consequently to the installation of the skylight (as service loss), the company noted that the thermal comfort was slightly reduced, especially in the warm season. Despite the capability of quantifying such impacts, thanks to the application of the framework, the company realized that an additional set of impacts had to be considered in the decision-making phase. 
The interviewee also appreciated the classification of the EEMs' impacts. Indeed, the interviewee proposed a change in the evaluation scale for a couple of attributes (i.e. the frequency of exploitation and maintenance). Interestingly, for some of the impacts, the attributes were deemed to be even with too abundant, in particular regarding resilience which was for the first time considered and thus with just a little knowledge over it.

\section{Concluding remarks and further research}

Developing a framework characterizing the impacts when adopting EEMs is crucial for industrial decision-makers as well as policy-makers. Indeed, thanks to an increased knowledge of the impacts related to an EEM, policy-makers could be better supported in developing the most effective policy actions to promote energy efficiency at the industrial level. Furthermore, a deeper knowledge of the impacts could more effectively lead to an increased understanding of the barriers behind the adoption of an EEM. This aspect is closely related to industrial decision-makers, who need, when undertaking their decisions, a much broader perspective on the whole set of possible impacts when adopting an EEM, both covering positive as well as negative impacts, but also distinguishing between implementation and service phase of an EEM. Here, the preliminary validation of the framework seemed to offer a positive feedback, since the managers interviewed confirmed that the new approach looks also to the installation and implementation phase, that should deserve a greater attention in the decision-making process. In addition, a clear definition of the negative impacts (perceived along the entire life of the EEM) was appreciated as a relevant element for a complete understanding of the impacts. In fact, the existence of, e.g., production disruption during the implementation phase of an EEM in Company B was considered as an important issue to be highlighted. Moreover, the preliminary application showed that the framework could bring an enhanced knowledge over the impacts, therefore representing a valuable tool in support of industrial decision-makers.

Additionally, and notable for a practical application of the framework, little research had so far paid much attention to describe in detail the attributes of an impact, thus going beyond the nature or the company area in which an impact may have an effect. In fact, as also shown by the preliminary interviews, different timescale attributes, as well as persistence and perception from several stakeholders, could modify the decision-making whether to adopt or not a specific EEM. We believe that, as another crucial element of novelty, the framework could lead to a different perspective when analysing barriers and drivers to specific EEMs. In particular, it would be interesting to study barriers and drivers to EEMs according to different impacts (positive or negative) in the implementation and service phases, and it would result particularly useful for the selection of the most promising EEMs to be promoted. Yet, we want to acknowledge a few limitations of our research: firstly, the quantification of the impacts has not been addressed in the present study. In this regard, it is worth 
considering that each impact could be measured according to many different metrics into industrial operations, plus the existence of a huge variety of industrial contexts could represent a crucial challenge that further research would deserve to address. Still, the impacts from the adoption of an EEM should be encompassed in a holistic framework able to, e.g., well describe and assign them to different areas in a company and production resources affected by the implementation of an EEM, which has been done in the present study. For this reason, we believe that further research could build upon the present framework a sound quantification of such impacts. Secondly, we have not yet provided an instrument to provide a unique overall judgment over the EEM in light of the benefits and losses. Regarding this limitation, we believe further research could develop specific tools in support of industrial decision-makers, also possibly capable to tune the relevance of highlighted impacts (according to their specific contexts). In particular, multi-attribute decision-making techniques, such as, e.g., Analytic Hierarchy Process (AHP) or Analytic Network Process (ANP), could leverage on the existing structure of the framework to build evaluation criteria for decisionmaking over EEMs.

In terms of additional research avenues, the novel framework could be exploited for further empirical research through the following streams: firstly, it would be interesting to apply the framework in a selected cluster of enterprises, so to understand common needs and opportunities. Here, even though in the preliminary validation into companies the proposed framework has dealt with different industrial contexts, we acknowledge that for robust considerations on the applicability in different contexts a larger sample is needed. Secondly, it would be possible to apply the framework in analysing several stakeholders within the same supply chain of an EEM, so to point out different perspectives and analyse existing mismatches (that lead an EEM to not being implemented by an end-user). Thirdly, it would be possible to analyse a single company with respect to several different EEMs, so to understand the possible synergies (either positive or negative) coming from the adoption of a set of EEMs. Fourthly, it would be quite interesting and challenging to seek whether the framework would perform out of the context for which it has been specifically developed, i.e. industrial energy efficiency. Fifthly, it would be quite relevant to point out existing energy efficiency benefits from the adoption of measures not designed for energy efficiency purposes (i.e. where energy efficiency resulted as a side effect not considered in the decision-making process). Finally, from a policy-making perspective, it would be possible to exploit the developed framework to describe a set of different companies with respect to the same EEM, so to develop the most appropriate means to foster the adoption of such measures.

\section{References}

Anderson, S.T. \& Newell, R.G., 2004. Information Programs for Technology Adoption: The Case of Energy-Efficiency Audits. Resource and Energy Economics 26 (1), 27-50.

Atabani, A.E., Saidur, R., Mekhilef, S., A review on energy saving strategies in industrial sector, Renewable and Sustainable Energy Reviews, 15(1), 150-168, 2011. 
Balaras, C.A., Dascalaki E., Gaglia, A., Droutsa, K., Energy conservation potential, HVAC installations and operational issues in Hellenic airports, Energy and buildings, 35(11), 1105-1120, 2003.

Blass, V., Corbett, C.J., Delmas, M.A., Muthulingam, S., 2014. Top management and the adoption of energy efficiency practices: Evidence from small and medium-sized manufacturing firms in the US. Energy, 65, 560-571.

Boyd, G., Pang, J.X., 2000. Estimating the linkage between energy efficiency and productivity. Energy Policy, 28(5): 289-296.

Bozorgi, A., 2015. Integrating value and uncertainty in the energy retrofit analysis in real estate investment- next generation of energy efficiency assessment tools, Energy Efficiency, 8(5):10151034.

Bunse, K., Vodicka, M., Schönsleben, P., Brülhart, M. Ernst, F. O., 2011. Integrating energy efficiency performance in production management-gap analysis between industrial needs and scientific literature, Journal of Cleaner Production, 19(6):667-679.

Brunke, J.-C., Johansson, M., \& Thollander, P., 2014. Empirical investigation of barriers and drivers to the adoption of energy conservation measures, energy management practices and energy services in the Swedish iron and steel industry. Journal of Cleaner Production, 84, 509525.

Cagno, E., Trianni, A., 2012. Analysis of the most effective energy efficiency opportunities in manufacturing primary metals, plastics, and textiles small- and medium-sized enterprises. Journal of Energy Resources Technologies, 134 (2), 021005.

Cagno, E. \& Trianni, A., 2013. Exploring Drivers for Energy Efficiency within Small- and Mediumsized Enterprises: First Evidences from Italian Manufacturing Enterprises. Applied Energy, 104, 276-285.

Cagno, E. \& Trianni, A., 2014. Evaluating the Barriers to Specific Industrial Energy Efficiency Measures: An Exploratory Study in Small and Medium-sized Enterprises. Journal of Cleaner Production, 82, 70-83.

Cagno, E., Worrell, E., Trianni, A. \& Pugliese, G., 2013. A novel approach for barriers to industrial energy efficiency. Renewable and Sustainable Energy Reviews, 19, 290-308.

Cagno, E., Trianni, A., Moschetta, D., 2016. Only Non-Energy Benefits when Adopting an EEM? Cases from Industry. Proceedings of the 2016 European Council for an Energy-Efficient Economy Summer Study on Industrial Efficiency Productivity. Berlin: ECEEE.

Cagno, E., Neri, A., Trianni, A., 2018. Broadening to sustainability the perspective of industrial decision-makers on the energy efficiency measures adoption: some empirical evidence. Energy Efficiency, 11(5), 1193-1210.

Carbon Trust, Compressed air - Opportunities for businesses, London, UK; 2012. p. 32. Available at: http://www.psee.org.za/downloads/publications/FPP7884 Compressed air WEB.pdf.

Choi, A.-S., Song, K.-D. Kim, Y.-S., The characteristics of photosensors and electronic dimming ballasts in daylight responsive dimming systems, Building and Environment, 40(1), 39-50, 2005.

Cooremans, C., 2007. Strategic fit of energy efficiency (Strategic and cultural dimensions of energy-efficiency investments). Proceedings of ECEEE summer study, La Colle sur Loup, France. ISBN: 978-91-633-0899-4.

Cooremans, C., 2011. Make it strategic! Financial investment logic is not enough. Energy Efficiency, 4, 473-492.

Dawn, B., Skumatz, L. A., 2007. New Non-Energy Benefits (NEBs) results in the commercial/industrial sectors, Proceedings of 2007 ECEEE Summer study, June 2007, La Colle sur Loup, France.

De Leon, P. M., Díaz, V. G.-P., Martínez, L. B. Márquez, A. C., 2012. A practical method for the maintainability assessment in industrial devices using indicators and specific attributes, Reliability Engineering \& System Safety, 100:84-92.

Doulos, L., Tsangrassoulis, A, Topalis, F., Quantifying energy savings in daylight responsive systems: The role of dimming electronic ballasts, Energy and Buildings, 40(1), 36-50, 2008. 
Doyle, F., Cosgrove, J. An Approach to optimising compressed air systems in production operations. International Journal of Ambient Energy, 39, 2, 194-201, 2018.

Du Plessis, G. E., Liebenberg, L., Mathews, E. H., The use of variable speed drives for costeffective energy savings in South African mine cooling systems, Applied Energy, 111, 16-27., 2013.

Elliott, R.N., Laitner, S., Pye, M., 1997. Considerations in the estimation of costs and benefits of industrial energy efficiency projects. In IECEC-97 Proceedings of the Thirty-Second Intersociety Energy Conversion Engineering Conference, July-August, Honolulu, USA.

European Council, 2012, Directive 2012/27/EU on energy efficiency, amending Directives 2009/125/EC and 2010/30/EC, and repealing Directives 2004/8/EC and 2006/32/EC.

[EIA], Energy Information Administration, 2014. International Energy Outlook 2014. U.S. Energy Information Administration Office of Integrated and International Energy Analysis U.S. Department of Energy, Washington, DC 20585, report no. DOE/EIA0484(2014), available at:

http://www.eia.gov/ieo

Eisenhardt, K.M., 1989. Building theories from case study research. The Academy of Management Review, 14, no. 4, 532-550.

Elliot, N. R., Laitner, S. \& Pye, M., 1997. Considerations in the estimation of costs and benefits of industrial energy efficiency projects. In Energy Conversion Engineering Conference, 1997. IECEC97., Proceedings of the 32nd Intersociety (Vol. 3, pp. 2143-2147). IEEE.

ETSU, Energy savings with motors and drives, Harwell, Didcot, Oxfordshire, UK; 1998. p. 53.

[EUROSTAT], 2015. Report from the commission to the European and the Council. Assessment of the progress made by Member States towards the national energy efficiency targets for 2020 and toward the implementation of the Energy Efficiency Directive 2012/27/EU as required by Article 24 . (3) of Energy efficiency Directive 2012/27/EU.

Finman, H. \& Laitner, J. A., 2001. Industry, Energy Efficiency and Productivity Improvements. Proceedings of the 2001 ACEEE Summer Study on Energy Efficiency in Industry. Washington DC, United States.

Finster, M. P. \& Hernke, M. T., 2014. Benefits organizations pursue when seeking competitive advantage by improving environmental performance. Journal of Industrial Ecology, 18(5), 652-662.

Fleiter, T., Schleich, J. \& Ravivanpong, P., 2012. Adoption of energy-efficiency measures in SMEs-An empirical analysis based on energy audit data from Germany. Energy Policy 51 (2012): 863-875.

Fleiter, T., Worrell, E. \& Wolfgang, E., 2011. Barriers to energy efficiency in industrial bottom-up energy demand models - a review. Renewable and Sustainable Energy Reviews, 15(6), 30993111. [GBEO] Good Practice, Case Study 219 - Two-speedmotors on ventilation fans, The Department of the Environment's Energy Efficiency Best Practice Programme, December 1997. Hall, N. P., Roth, J. A., 2003. Non-energy benefits from commercial and industrial energy efficiency programs: Energy efficiency may not be the best story. Proceeding of the 2003 International Energy Program Evaluation Conference: 689-702.

Hall, N. P., Roth, J. A., 2004. Non-Energy Benefits from Commercial \& Industrial Programs: What Are the Benefits and Why Are They Important to Participants?. Proceedings of the 2004 ACEEE summer study on energy efficiency in buildings, August 2004, Pacific Grove, USA.

Heffner, G. \& Campbell, N., 2011. Evaluating the co-benefits of low-income energy-efficiency programmes. Workshop Report, OECD/IEA, Paris, available at:

https://www.iea.org/publications/freepublications/publication/low income energy efficiency.pdf .

Imbierowicz, K., Skumatz, L.A., Gardner, J., 2006. Net NEB Multipliers for Economic Impacts: Detailed Analysis of Differences by Program Type and State. Proceedings of the 2006 ACEEE summer study on energy efficiency in buildings, August 2006, Pacific Grove, USA.

[IEA], International Energy Agency, 2012. Spreading the net: the multiple benefits of energy efficiency improvements. OECD/IEA, Paris, France, available at:

https://www.iea.org/publications/insights/insightpublications/Spreading the Net.pdf . 
[IEA], International Energy Agency, 2014. Capturing the multiple benefits of energy efficiency. Paris, France; 2014, ISBN 978-92-64-22072-0, p. 232.

[IEA], International Energy Agency, 2015. Accelerating Energy Efficiency in Small and Mediumsized Enterprises. OCED/EIA, Paris, available at:

https://www.iea.org/publications/freepublications/publication/SME 2015.pdf .

[IEA], International Energy Agency, 2017. Market report series, Energy Efficiency 2017. Available at: http://www.iea.org/publications/freepublications/publication/Energy_Efficiency_2017.pdf Ihm, P., Nemri, A., Krarti, M., Estimation of lighting energy savings from daylighting, Building and Environment, 44(3), 509-514, 2009.

Ikaga, T., Eguchi, R., Murakami, S., Iwamae, A., Hoshi, T., Mizuishi, T., Kawakubo, S., Okumura, $\mathrm{K}$. Evaluation of investment in residential thermal insulation considering non-energy benefits delivered by health, Journal of Environmental Engineering, 76, 666, 735-740, 2011.

Kómar, L., Kocifaj, M., Uncertainty of daylight illuminance on vertical building façades when determined from sky scanner data: A numerical study, Solar Energy, 110, 15-21, 2014.

Kuzuki, R., lkaga, T., Murakami, S, Kato, Y., Tanaka, T., Ikuta, Y. Study on non-energy benefits (neb) by area-wide energy utilization, Journal of Environmental Engineering, 75, 656, 915-921, 2010.

Laitner, J. A., Ruth, M. B. \& Worrell, E., 2001. Incorporating the productivity benefits into the assessment of cost effective energy savings potential using conservation supply curves. Lawrence Berkeley National Laboratory. Available at: http://escholarship.org/uc/item/49g4p179

Lazar, J., Colburn, K., 2013. Recognizing the Full Value of Energy Efficiency: what's Under the Feel-good Frosting of the World's Most Valuable Layer Cake of Benefits, Regulatory Assistance Project. Available at:

http://climateandenergy.org/admin_upload/EE/RAP_LazarColburn_LayerCakePaper_2013_Sept_9 .pdf

[LBNL] Lawrence Berkeley National Laboratory, Improving compressed air systems performance. A sourcebook for industry, Washington, DC, US; 2003. p. 128.

Leephakpreeda, T., Adaptive occupancy-based lighting control via grey prediction, Building and environment, 40(7), 881-886, 2005.

Li, D.H., Tsang, E.K., An analysis of daylighting performance for office buildings in Hong Kong, Building and Environment, 43(9), 1446-1458, 2008.

Lilly, P. \& Pearson, D., 1999. Determining the full value of industrial efficiency programs.

Proceedings from the 1999 ACEEE Summer Study on Energy Efficiency in Industry, Saratoga Springs, NY, June 15-18 (pp. 349-362).

Lung, R. B., McKane, A., Leach, R. \& Marsh, D., 2005. Ancillary savings and production benefits in the evaluation of industrial energy efficiency measures. Proceedings of the 2005 American Council for an Energy-Efficient Economy Summer Study on Energy Efficiency in Industry. Washington, DC: ACEEE.

Martirano, L., Manganelli, M., Parise, L., Sbordone, D.A., Design of a fuzzy-based control system for energy saving and users comfort, Environment and Electrical Engineering (EEEIC), 2014 14th International Conference on Environment and Electrical Engineering (EEEIC), Krakow (Poland), $10^{\text {th }}-12^{\text {th }}$ May, 2014.

Mills, E. \& Rosenfeld, A., 1996. Consumer non-energy benefits as a motivation for making energyefficiency improvements. Energy, 21(7), 707-720.

Mills, E., Shamshoian, G., Blazek, M., Naughton, P., Seese, R.S., Tschudi, W., Sartor, D., The business case for energy management in high-tech industries. Energy Efficiency, 1, 5-20, 2008.

Murphy, S., Kissock, K., Simulating Energy Efficient Control of Multiple-Compressor Compressed Air Systems, 2015, Mechanical and Aerospace Engineering Faculty Publications. 144.

http://ecommons.udayton.edu/mee fac pub/144

[NLPIP] National Lighting Product Information Program, Specifier Report: Photoensors. Dimming and Switching Systems for Daylight Harvesting, 7 (1), 2007. Available at:

http://www.Irc.rpi.edu/programs/NLPIP/PDF/PRINT/SR Photosensors.pdf 
Nehler, T., Rasmussen, J., 2016. How do firms consider non-energy benefits? Empirical findings on energy-efficiency investments in Swedish industry. Journal of Cleaner Production, 113, 472482.

Nehler, T., 2018. Linking energy efficiency measures in industrial compressed air systems with non-energy benefits - A review. Renewable and Sustainable Energy Reviews, 89, 72-87.

Nehler, T., Parra, R., Thollander, P., 2018a. Implementation of energy efficiency measures in compressed air systems: barriers, drivers and non-energy benefits. Energy Efficiency, 11, no. 5, 1281-1302.

Nehler, T., Thollander, P, Fredriksson, L., Friberg, S., Nordberg, T., 2018b. Non-Energy Benefits of Swedish Energy Efficiency Policy Instruments - A Three-Levelled Perspective. Proceedings of ECEEE 2018 Industrial study, Berlin (Germany) 11-13 June 2018.

Ozdemir, E., Energy conservation opportunities with a variable speed controller in a boiler house, Applied Thermal Engineering, 24(7), 981-993, 2004.

Pagell, M., Gobeli, D., 2009. How plant managers' experiences and attitudes toward sustainability relate to operational performance. Production and Operations Management, 18, 278-299.

Palm, J. \& Thollander, P., 2010. An interdisciplinary perspective on industrial energy efficiency. Applied Energy, 87(10), 3255-3261.

Pearson, D., Skumatz, L.A., 2002. Non-Energy Benefits Including Productivity, Liability, Tenant Satisfaction, and Others- What Participant Surveys Tell Us about Designing and Marketing Commercial Programs. Proceedings of the 2002 Summer Study on Energy Efficiency in Buildings (p. 2).

Piette, M. A. \& Nordman, B., 1996. Costs and benefits from utility-funded commissioning of energy-efficiency measures in 16 buildings. (No. CONF-960254--). American Society of Heating, Refrigerating and Air-Conditioning Engineers, Inc., Atlanta, GA (United States).

Pye, M., McKane, A., 1999. Enhancing shareholder value: Making a more compelling energy efficiency case to industry by quantifying non-energy benefits. Proceedings of the 2006 ACEEE summer study on energy efficiency in industry, June 1999, Saratoga Springs, USA.

Pye, M. \& McKane, A., 2000. Making a stronger case for industrial energy efficiency by quantifying non-energy benefits. Resources, Conservation and Recycling, 28(3), 171-183.

Rasmussen, J., 2017. The additional benefits of energy efficiency investments - a systematic literature review and a framework for categorisation. Energy Efficiency, 10, no. 6, 1401-1418.

Rohdin, P., Thollander, P., 2006. Barriers to and driving forces for energy efficiency in the nonenergy intensive manufacturing industry in Sweden. Energy 31(12):1836-1844.

Roos, F., Johansson, H., Wikander, J., Optimal selection of motor and gearhead in mechatronic applications, Mechatronics, 16(1), 63-72., 2006.

Sachs, H., Nadel, S., Amann, J. T., Tuazon, M., Mendelsohn, E., Rainer, L., Todesco, G., Shipley, D. Adelaar, M., Emerging energy-saving technologies and practices for the buildings sector as of 2004, American Council for an Energy-Efficient Economy (ACEEE), Davis Energy Group, and Marbek Resource Consultants, Washington, DC, Report, (A042), 214-246, 2004.

Saidur, R., A review on electrical motors energy use and energy savings, Renewable and Sustainable Energy Reviews, 14(3), 877-898, 2010.

Sandberg, P. \& Söderström, M., 2003. Industrial energy efficiency: the need for investment decision support from a manager perspective. Energy Policy, 31(15), 1623-1634.

Schiavon, S., Melikov, A., Energy saving and improved comfort by increasing, Energy and Buildings Volume 40, Issue 10, 1954-1960, 2008.

Schleich, J., 2009. Barriers to energy efficiency: a comparison across the German commercial and services sector. Ecological Economics, 68(7), 2150-2159.

Schmehl, C., McKinley, M., McBride, W., Kavanaugh, J. Paes, R., Adjustable speed drive selection for electric submersible pumps, In Petroleum and Chemical Industry Technical Conference (PCIC): IEEE (pp. 201-216). San Francisco (US), 8 ${ }^{\text {th }}-10^{\text {th }}$ Sep 2014. 
Schweitzer, M., Tonn, B. Non-energy benefits of the US Weatherization Assistance Program: A summary of their scope and magnitude. Applied Energy. 2003. 76(4), 321-325.

Shakweh, Y., Power Electronics Handbook: Devices, Circuits and Applications, Second Edition. Chapter 32: Drives types and specifications. Edited by Rashid M.H., Academic Press, Elsevier. 2006: ISBN 10: 0120884798.

Shen, E., Hu, J., Patel, M., Energy and visual comfort analysis of lighting and daylight control strategies, Building and Environment, 78, 155-170, 2014.

Shirali, Gh. A., Motamedzade, M., Mohammadfam, I., Ebrahimipour, V., Moghimbeigi A., 2015. Assessment of resilience engineering factors based on system properties in a process industry, Cognition, Technology \& Work, 18(1):19-31.

Skumatz, L. A., Dickerson, C. A., 1998. Extra! Extra! Non-energy benefits swamp load impacts for PG and E program!, (No. CONF-980815--). Skumatz Economic Research Associates, Inc., Seattle, WA (US).

Skumatz, L. A., Dickerson, C. A., Coates, B., 2000. Non-Energy Benefits in the Residential and Non-Residential Sectors - Innovative Measurements and Results for Participant Benefits, In Proceedings of the 2000 ACEEE Summer Study on Energy Efficiency in Buildings (Vol. 8, p. 364). Skumatz, L. A. \& Gardner, J., 2005. Methods and results for measuring non-energy benefits in the commercial and industrial sectors. Proceedings of ACEEE Summer Study on Energy Efficiency in Industry: Cutting the High Cost of Energy. West Point, New York, 163-176.

Skumatz, L.A., Gardner, J., 2006. Differences in the Valuation of Non-Energy Benefits According to Measurement Methodology: Causes and Consequences, Proceedings of the Association for Energy Service Professionals NESP Conference.

Skumatz, L., A, Efficiency Programs' Non-Energy Benefits: How States are finally making progress in reducing bias in cost-effectiveness tests. Electricity Journal, 28, 8, 96-109, 2015.

Smith-McLain, L., Skumatz, L.A., Gardner, J., 2006. Attributing NEB Values to Specific Measures: Decomposition Results from Programs with Multiple Measures. Proceedings 2006 Summer Study on Energy Efficiency in Buildings. Monterey, CA. American Council for an Energy Efficient Economy, 2006.

Sorrell, S., Mallett, A. \& Nye, S., 2010. Barriers to industrial energy efficiency: a literature review. Brighton: SPRU, University of Sussex (UK): In: Background study for the UNIDO Industrial Development Report (IDR) 'Industrial energy efficiency pays, why is it not happening?'.

Sorrell, S., O'Malley, E., Schleich, J. \& Scott, S., 2004. The economics of energy efficiency. Cheltenham, UK: Edward Elgar Publishing p. 349.

Thollander, P. \& Ottosson, M., 2008. An energy efficient Swedish pulp and paper industryexploring barriers to and driving forces for cost-effective energy efficiency investments. Energy Efficiency, 1(1), 21-34.

Tonn, B., Peretz, State-level benefits of energy efficiency. Energy Policy, 35, 3665-3674, 2007. Trianni, A., Cagno, E., 2012. Dealing with barriers to energy efficiency and SMEs: Some empirical evidences. Energy, 37, 494-504.

Trianni, A., Cagno, E., Thollander, P., \& Backlund, S., 2013. Barriers to industrial energy efficiency in foundries: a European comparison. Journal of Cleaner Production, 40, 161-176.

Trianni, A., Cagno, E., \& De Donatis, A., 2014. A framework to characterize energy efficiency measures. Applied Energy, 118, 207-220.

Trianni, A., Cagno, E. \& Farnè, S. 2016. Industrial Energy Efficiency: A Broad Investigation of Barriers and Drivers in the Decision-Making Process among Small and Medium-sized Enterprises. Applied Energy, 162, 1537-1551.

Trianni, A., Cagno, E., Marchesani, F., Spallina, G., 2017. Classification of drivers for industrial energy efficiency and their effect on the barriers affecting the investment decision-making process. Energy Efficiency, 10, 199-215. 
Thollander, P., Backlund, S., Trianni, A., Cagno, E., 2013. Beyond barriers - A case study on driving forces for improved energy efficiency in the foundry industries in Finland, France, Germany, Italy, Poland, Spain, and Sweden, Applied Energy, 111, 636-643.

[UNECE]. United Nations economic commission for Europe. Overcoming barriers to investing in energy efficiency, United Nations publication ISBN 978-92-1-117091-7, 2017.

[USDOE/EIA]. United States Department of Energy, Energy Information Administration.

International Energy Outlook 2016. Report no. DOE/EIA-0484(2016), May 2016, Washington DC, US.

[USDOE] United Stated Department of Energy, Premium efficiency motor selection and application guide - A Handbook for industry, 2014. Available at:

https://www.energy.gov/sites/prod/files/2014/04/f15/amo motors handbook web.pdf

[USDOE] United States Department of Energy, United States Industr Industrial Electric Motor Systems Market Market Opportunities Assessment, Washington, DC, US; 2002. p. 386.

Vine, E., Mills, E., Chen, A., 2000. Energy-efficiency and renewable energy options for risk management and insurance loss reduction. Energy, 25(2):131-147.

Vine, E., 2011. Addressing Non-Energy Benefits In The Cost-Effectiveness Framework, report for CPUC Energy Division, available at:

https://library.cee1.org/system/files/library/9734/CEE EvalNEBCostEffect.pdf

Worrell, E., Laitner, J. A., Ruth, M. \& Finman, H., 2003. Productivity benefits of industrial energy efficiency measures. Energy, 28(11), 1081-1098.

Worrell, E., Angelini, T. Masanet, E., 2010. An ENERGY STAR® Guide for Identifying Energy Savings in Manufacturing Plants. Available at:

https://www.energystar.gov/ia/business/industry/downloads/Managing Your Energy Final LBNL-

3714E.pdf

Wulfinghoff, D., Energy efficiency manual: for everyone who uses energy, pays for utilities, controls energy usage, designs and builds, is interested in energy and environmental preservation, Energy Institute Press, 1999.

Zhang, S., Worrell, E., Crijns-Graus, V., Wagner, F., Cofala, J., 2014. Co-benefits of energy efficiency improvement and air pollution abatement in the Chinese iron and steel industry. Energy, 78:333-345.

Zhang, S., Worrell, E., Crijns-Graus, V., 2015. Mapping and modeling multiple benefits of energy efficiency and emission mitigation in China's cement industry at the provincial level. Applied Energy, 155:35-58. 
Figure 1 - Categorization of EEM impacts

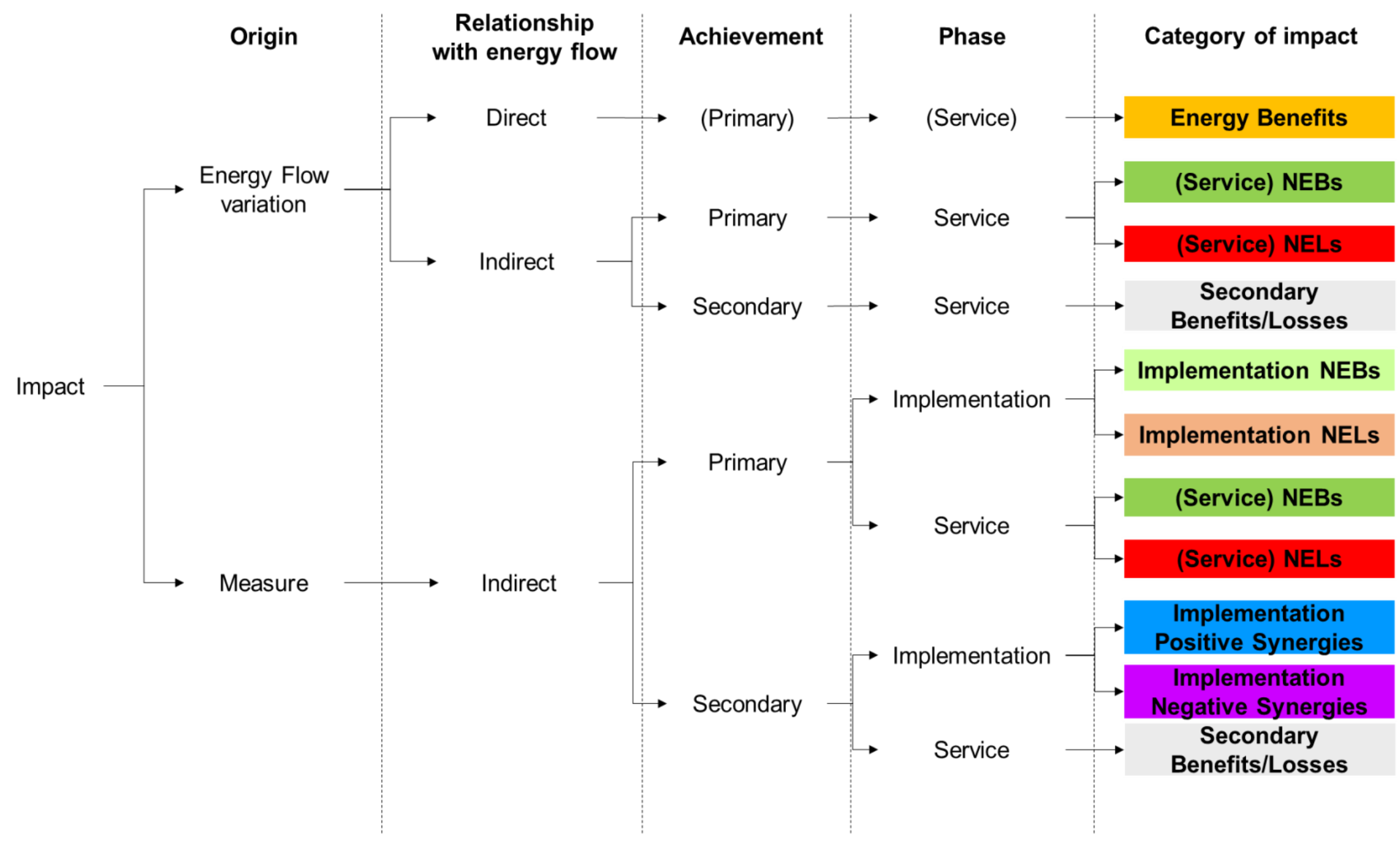


Figure 2 - Definition of the framework displaying the set of impacts from adoption of an EEM, taking inspiration from Cagno et al. (2016): focus is given to both positive (benefits) or negative (losses) impacts, as well as in implementation and service phase. The positioning is to be intended with reference to quadrants only.

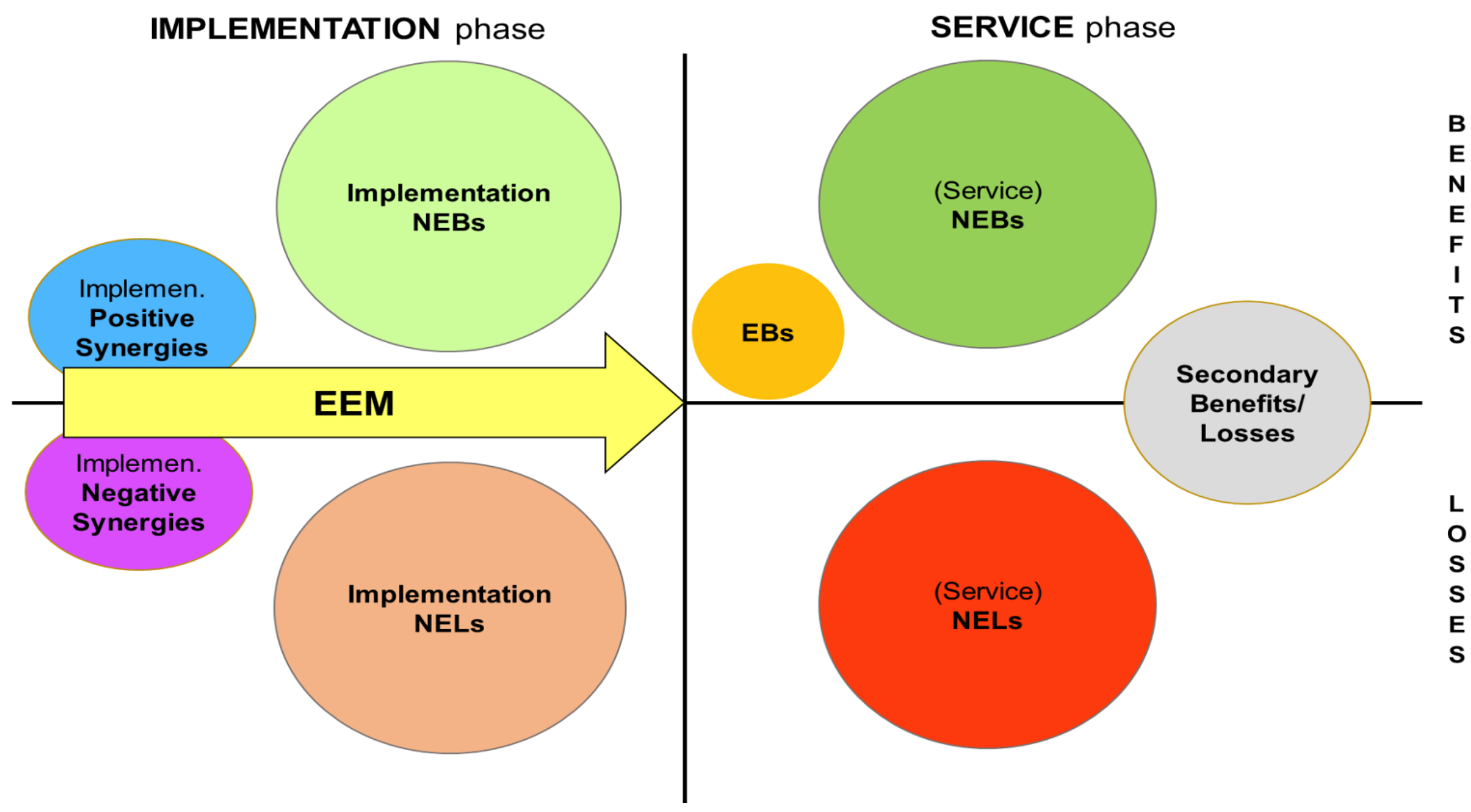


Table 1. Overview of literature contributions on Non-Energy Benefits for industrial EEMs.

\begin{tabular}{|c|c|c|c|c|c|}
\hline Authors & Year & Type & Focus & Implementation/Service phase & Benefits/Losses \\
\hline Mills and Rosenfelds & 1996 & Journal & Industrial sector & Service & Benefits \\
\hline Piette and Nordman & 1996 & Conference proceedings & Commercial and Industrial sector & Service / Implementation & Benefits and Losses \\
\hline Elliott et al. & 1997 & Conference proceedings & Industrial sector & Service & Benefits \\
\hline Skumatz and Dickerson & 1998 & Conference proceedings & Industrial sector & Service & Benefits \\
\hline Lilly and Pearson & 1999 & Report & Industrial sector & Service & Benefits \\
\hline Pye and McKane & 1999 & Conference proceedings & Industrial sector & Service & Benefits \\
\hline Boyd and Pang & 2000 & Journal & Industrial sector & Service & Benefits \\
\hline Pye and McKane & 2000 & Journal & Industrial sector & Service & Benefits \\
\hline Skumatz et al. & 2000 & Conference proceedings & Residential sector & Service & Benefits \\
\hline Vine et al. & 2000 & Journal & Insurance, industrial sector, policy-makers & Service & Benefits \\
\hline Finman and Laitner & 2001 & Conference proceedings & Industrial sector & Service & Benefits \\
\hline Laitner et al. & 2001 & Conference proceedings & Industrial sector & Service & Benefits \\
\hline Pearson and Skumatz & 2002 & Report & Commercial sector & Service & Benefits and Losses \\
\hline Hall and Roth & 2003 & Report & Policy-makers & Service & Benefits \\
\hline Worrell et al. & 2003 & Journal & Industrial sector & Service & Benefits \\
\hline Gillingham et al. & 2004 & Report & Policy-makers & Service & Benefits \\
\hline Hall and Roth & 2004 & Conference proceedings & Commercial and Industrial sector & Service & Benefits \\
\hline Lung et al. & 2005 & Conference proceedings & Industrial sector & Service & Benefits \\
\hline Skumatz and Gardner & 2005 & Conference proceedings & Commercial and Industrial sector & Service & Benefits and Losses \\
\hline Imbierowicz et al. & 2006 & Conference proceedings & Policy-makers & Service & Benefits and Losses \\
\hline Skumatz and Gardner & 2006 & Report & Industrial sector & Service & Benefits and Losses \\
\hline Smith-McClain et al. & 2006 & Conference proceedings & Residential and commercial sector & Service & Benefits and Losses \\
\hline Dawn and Skumatz & 2007 & Conference proceedings & Commercial and Industrial sector & Service & Benefits and Losses \\
\hline Mills et al. & 2008 & Journal & Industrial sector & Service & Benefits \\
\hline Giannantoni & 2009 & Conference proceedings & Policy-makers & Service & Benefits and Losses \\
\hline Kuzuki et al. & 2010 & Journal & Policy-makers & Service & Benefits \\
\hline Worrell et al. & 2010 & Report & Industrial sector & Service & Benefits \\
\hline Bunse et al. & 2011 & Journal & Industrial sector & Service & Benefits \\
\hline Cooremans & 2011 & Journal & Industrial sector & Service & Benefits \\
\hline Ikaga et al. & 2011 & Journal & Policy-makers & Service & Benefits \\
\hline Vine & 2011 & Report & Policy-makers & Service & Benefits \\
\hline Fleiter et al. & 2012 & Journal & Industrial sector and policy-makers & Service & Benefits and Losses \\
\hline Heffner and Campbell & 2012 & Report & Policy-makers & Service & Benefits and Losses \\
\hline IEA & 2012 & Report & Policy-makers & Service & Benefits and Losses \\
\hline Finster and Hernke & 2014 & Journal & Industrial sector & Service & Benefits \\
\hline IEA & 2014 & Report & Policy-makers & Service & Benefits \\
\hline Trianni et al. & 2014 & Journal & Industrial sector & Service & Benefits and Losses \\
\hline Zhang et al. & 2014 & Journal & Industrial sector & Service & Benefits \\
\hline Bozorgi & 2015 & Journal & Real estate & Service & Benefits and Losses \\
\hline IEA & 2015 & Report & Policy-makers & Service & Benefits \\
\hline Skumatz & 2015 & Journal & Industrial sector & Service & Benefits and Losses \\
\hline Zhang et al. & 2015 & Journal & Industrial sector & Service & Benefits \\
\hline
\end{tabular}




\begin{tabular}{|c|c|c|c|c|c|}
\hline Nehler and Rasmussen & 2016 & Journal & Industrial sector & Service & Benefits \\
\hline Rasmussen & 2017 & Journal & Industrial sector & Service & Benefits \\
\hline Doyle and Cosgrove & 2018 & Journal & Industrial sector & Service & Benefits \\
\hline Nehler & 2018 & Journal & Industrial sector & Service & Benefits \\
\hline Nehler et al. & $2018 a$ & Journal & Industrial sector & Service & Benefits \\
\hline Nehler et al. & $2018 b$ & Conference proceedings & Industrial sector and policy-makers & Service & Benefits \\
\hline
\end{tabular}


Table 2. Definition of the additional attributes of the impacts supporting the decision-maker in the evaluation of adopting an EEM.

\begin{tabular}{|c|c|c|c|}
\hline Category & Attribute & Description & Evaluation \\
\hline \multirow{3}{*}{$\begin{array}{l}\text { Nature and } \\
\text { Beneficiary }\end{array}$} & Nature & $\begin{array}{l}\text { Nature of interest the impact refers to, as from (Lung et al., 2005), } \\
\text { (Bunse et al. 2011), (Piette and Nordman 1996), (Worrell et al. 2003), } \\
\text { (Mills and Rosenfeld 1996) and (Skumatz and Dickerson 1998), with } \\
\text { proper modifications to suit an industrial decision-making context. }\end{array}$ & $\begin{array}{l}\text { Production, maintenance, work } \\
\text { environment conditions, ..., other } \\
\text { industrial operations related }\end{array}$ \\
\hline & Targeted area & $\begin{array}{l}\text { Area of the organization where the considered impact is perceived. The } \\
\text { areas proposed are mainly, but not exclusively physical departments of } \\
\text { the organization. }\end{array}$ & Area of the organisation \\
\hline & Extension & $\begin{array}{l}\text { Number of beneficiaries in the area that are involved by the impact's } \\
\text { manifestation. The last two features, together, can be used to well } \\
\text { describe the beneficiaries, as suggested by (IEA 2014), (Heffner and } \\
\text { Campbell 2011), (Skumatz et al. 2000). }\end{array}$ & Number of beneficiaries identified \\
\hline \multirow{4}{*}{ Persistence } & Duration & $\begin{array}{l}\text { Duration of the impacts, considered from the beginning of the service } \\
\text { phase (in case of service impacts) or from the beginning of the life of } \\
\text { the measure (in case of intervention-originated impacts). Property } \\
\text { defined consequently to (Heffner and Campbell 2011). }\end{array}$ & $\begin{array}{l}\text { Within the time horizon based on the } \\
\text { life of the EEM }\end{array}$ \\
\hline & Resilience & $\begin{array}{l}\text { Description of the intrinsic ability of the impact to adapt and react } \\
\text { before, during and after the system changes. (Shirali et al. 2015). }\end{array}$ & Scale from 0 (nothing) to 4 (very high) \\
\hline & Maintainability & $\begin{array}{l}\text { Need for additional maintenance of the impact with respect to the tasks } \\
\text { scheduled for the EEM maintenance. According to De Leon et al. } \\
\text { (2012), it is evaluated through a weighted average, considering the } \\
\text { ergonomics of the tasks, the standardization of spare parts and, finally, } \\
\text { the speed of execution. }\end{array}$ & $\begin{array}{l}\text { Scale from } 0 \text { (not possible) to } 4 \text { (no } \\
\text { need to conduct additional efforts) }\end{array}$ \\
\hline & Stability & $\begin{array}{l}\text { Evolution with respect to the time of the magnitude of the impact on the } \\
\text { plant. }\end{array}$ & $\begin{array}{l}\text { Indication of the behaviour (stable, } \\
\text { growing, de-growing, ...) }\end{array}$ \\
\hline \multirow{2}{*}{ Timescale } & Peak & Time when the impact has a peak in its magnitude. & $\begin{array}{l}\text { Within the time horizon based on the } \\
\text { life of the EEM }\end{array}$ \\
\hline & Frequency of Exploitation & $\begin{array}{l}\text { Possibilities to get advantage of an impact according to its duration and } \\
\text { maintainability over the lifetime of the EEM considered. }\end{array}$ & Range of frequencies \\
\hline \multirow{4}{*}{ Perception } & Customers & Perception from the customers of the impact. & Scale from 0 (nothing) to 4 (very high) \\
\hline & Suppliers & Perception from the suppliers of the impact. & Scale from 0 (nothing) to 4 (very high) \\
\hline & Operators & Perception from the operators of the impact. & Scale from 0 (nothing) to 4 (very high) \\
\hline & Local community & Perception from the local community of the impact. & Scale from 0 (nothing) to 4 (very high) \\
\hline Cash-flow & Generation & $\begin{array}{l}\text { Possibility to generate a cash flow thanks to the impact arisen. The } \\
\text { cash flow can be a cash inflow or, alternatively, a reduction of the cash } \\
\text { outflows. }\end{array}$ & Scale from 0 (nothing) to 4 (very high) \\
\hline
\end{tabular}


Table 3 - Measures selected for the literature validation. Source: excerpt from Trianni et al. (2014).

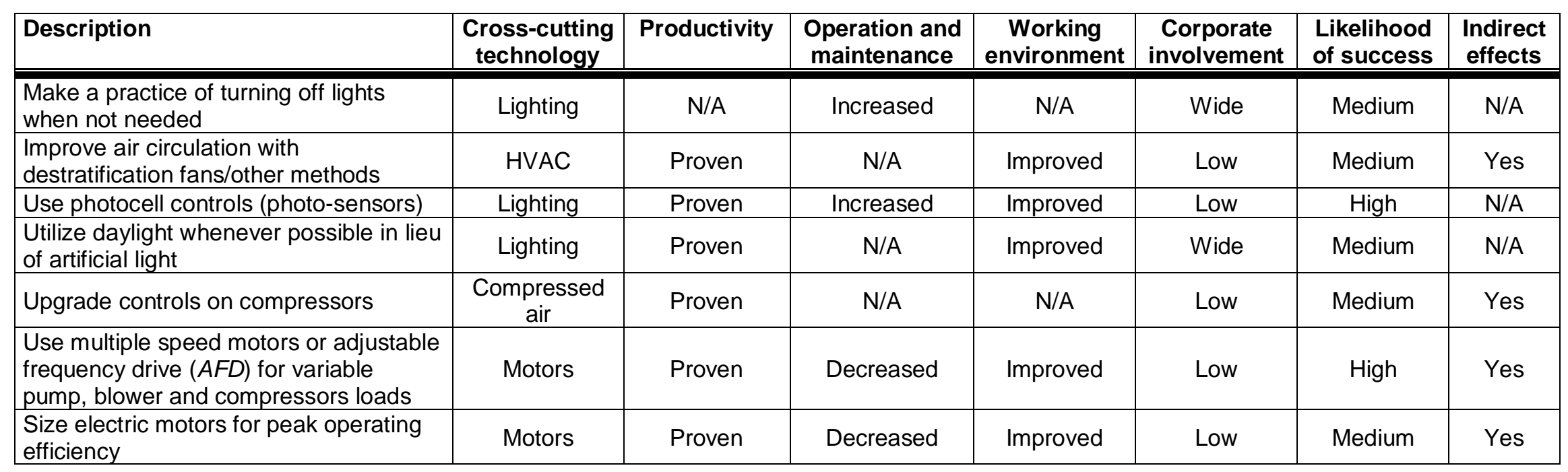


Table 4 - Distribution of the benefits/losses for each EEM considered

\begin{tabular}{|c|c|c|c|c|c|c|c|c|}
\hline $\begin{array}{c}\text { Description } \\
\text { of EEM }\end{array}$ & $\begin{array}{l}\text { Energy } \\
\text { saving }\end{array}$ & $\begin{array}{c}\text { Energy } \\
\text { benefits } \\
\end{array}$ & Service NEBs & Service NELs & $\begin{array}{c}\text { Implementation } \\
\text { NEBs }\end{array}$ & $\begin{array}{c}\text { Implementation } \\
\text { NELs }\end{array}$ & $\begin{array}{c}\begin{array}{c}\text { Secondary Benefits / } \\
\text { Losses }\end{array} \\
\end{array}$ & References \\
\hline $\begin{array}{l}\text { Make a } \\
\text { practice of } \\
\text { turning off } \\
\text { lights when } \\
\text { not needed }\end{array}$ & $\begin{array}{l}\text { Up to } 5 \% \\
\text { of energy } \\
\text { previously } \\
\text { required } \\
\text { for } \\
\text { lighting } \\
\text { purpose }\end{array}$ & $\begin{array}{l}\text { - Reduced } \\
\text { energy } \\
\text { expenditures } \\
\text { from reduced } \\
\text { energy flow } \\
\text { - Reduced } \\
\text { emissions from } \\
\text { reduced energy } \\
\text { flow (e.g. } \\
\text { reduced } \mathrm{CO}_{2} \\
\text { emissions) }\end{array}$ & $\begin{array}{l}\text { - Reduced reliability of the } \\
\text { measure } \\
\text { - Permits the check of the } \\
\text { effects of other control } \\
\text { systems }\end{array}$ & $\begin{array}{l}\text { - Increased need for labour } \\
\text { - Reduced equipment life }\end{array}$ & & $\begin{array}{l}\text { - Training of the } \\
\text { operators required }\end{array}$ & $\begin{array}{l}\text { - Quick discovery of } \\
\text { premature switching and } \\
\text { discomfort (Sec. Benefit); } \\
\text { - Facilitated monitoring of } \\
\text { operations and } \\
\text { occupancy (Sec. Benefit); } \\
\text { - Easier to determine the } \\
\text { proper time delay (S Sec. } \\
\text { Benefit B) }\end{array}$ & $\begin{array}{l}\text { Wulfinghoff, } 1999 \\
\text { Li and Tsang, } 2008 \\
\text { Leephakpreeda, } 2005\end{array}$ \\
\hline $\begin{array}{l}\text { Improve air } \\
\text { circulation } \\
\text { with } \\
\text { destratificatio } \\
\text { n fans/other } \\
\text { methods }\end{array}$ & $\begin{array}{l}\text { Every } \\
\text { degree } \\
\text { added on } \\
\text { the } \\
\text { thermosta } \\
\text { t can } \\
\text { save } 6 \%- \\
8 \% \text {, } \\
\text { reaching } \\
16-32 \% \\
\text { of total } \\
\text { saving }\end{array}$ & $\begin{array}{l}\text { - Reduced } \\
\text { energy } \\
\text { expenditures } \\
\text { from the } \\
\text { reduced energy } \\
\text { flow } \\
\text { - Reduced } \\
\text { emissions from } \\
\text { reduced energy } \\
\text { flow (e.g. } \\
\text { reduced } \mathrm{CO}_{2} \\
\text { emissions) }\end{array}$ & $\begin{array}{l}\text { - Lower heating/cooling } \\
\text { requirements; } \\
\text { - Prevention of coil freezing; } \\
\text { - Prevention of damages at } \\
\text { ducts with freezing weather; } \\
\text { - Uniformity of environmental } \\
\text { conditions; } \\
\text { - Improved thermal comfort; } \\
\text { - Reduced emitted } \\
\text { noise/vibration; } \\
\text { - Increased control on the } \\
\text { temperature; } \\
\text { - Increased comfort for the } \\
\text { operators }\end{array}$ & & $\begin{array}{l}\text { - Improved } \\
\text { monitoring of the } \\
\text { system state }\end{array}$ & $\begin{array}{l}\text { - Variation of the } \\
\text { layout }\end{array}$ & $\begin{array}{l}\text { - Improved of work } \\
\text { environ. with economizer } \\
\text { cycle (Sec. Benefit) }\end{array}$ & $\begin{array}{l}\text { Worrell et al., } 2010 \\
\text { Wulfinghoff, } 1999 \\
\text { Balaras et al., } 2003\end{array}$ \\
\hline $\begin{array}{l}\text { Use photocell } \\
\text { controls } \\
\text { (photo- } \\
\text { sensors) }\end{array}$ & $\begin{array}{l}\text { Occupanc } \\
\text { y sensors } \\
\text { can save } \\
10 \% \text { to } \\
25 \% \text { of a } \\
\text { facility's } \\
\text { lighting } \\
\text { energy } \\
\text { use }\end{array}$ & $\begin{array}{l}\text { - Reduced } \\
\text { energy } \\
\text { expenditures } \\
\text { from the } \\
\text { reduced energy } \\
\text { flow } \\
\text { - Reduced } \\
\text { emissions from } \\
\text { reduced energy } \\
\text { flow (e.g. } \\
\text { reduced } \mathrm{CO}_{2} \\
\text { emissions) }\end{array}$ & $\begin{array}{l}\text { - Adjustment of lighting cond., } \\
\text { keeping constant conditions; } \\
\text { - Higher flexibility of lighting }\end{array}$ & $\begin{array}{l}\text { - Reduced reliability of the } \\
\text { equipment; } \\
\text { - Increased comfort for the } \\
\text { operators; } \\
\text { - Increased addiction to } \\
\text { external conditions; } \\
\text { - Frequent switching in case of } \\
\text { unstable weather }\end{array}$ & & $\begin{array}{l}\text { - Proper calibration } \\
\text { of the sensors } \\
\text { required; } \\
\text { - Issues with } \\
\text { sensors positioning }\end{array}$ & $\begin{array}{l}\text { - Reduction of useless } \\
\text { switching with the } \\
\text { definition of a dead-band } \\
\text { (Sec. Benefit) }\end{array}$ & $\begin{array}{l}\text { Li and Tsang, } 2008 \\
\text { Sachs et al., } 2004 \\
\text { Choi et al., } 2005 \\
\text { Doulos et al., } 2008 \\
\text { Ihm et al., 2009 } \\
\text { NLPIP, } 1998\end{array}$ \\
\hline $\begin{array}{l}\text { Utilize } \\
\text { daylight } \\
\text { whenever } \\
\text { possible in } \\
\text { lieu of } \\
\text { artificial light }\end{array}$ & $\begin{array}{l}\text { Reduce } \\
\text { up to the } \\
70 \% \text { the } \\
\text { electric } \\
\text { load for }\end{array}$ & $\begin{array}{l}\text { - Reduced } \\
\text { energy } \\
\text { expenditures } \\
\text { from the } \\
\text { reduced energy } \\
\text { flow }\end{array}$ & $\begin{array}{l}\text { - Increased comfort for the } \\
\text { operators; } \\
\text { - Fluctuation in the light } \\
\text { utilization; } \\
\text { - Increased addiction to } \\
\text { external conditions; }\end{array}$ & $\begin{array}{l}\text { - Unsatisfactory conditions with } \\
\text { paperwork; } \\
\text { - Higher cooling requirements; } \\
\text { - HID becomes inadequate; } \\
\text { - Need to prevent water } \\
\text { leakage: }\end{array}$ & $\begin{array}{l}\text { - Flexibility of the } \\
\text { layout of the } \\
\text { skylights }\end{array}$ & $\begin{array}{l}\text { - Structural } \\
\text { changes needed } \\
\text { for the installation; } \\
\text { - Need for proper } \\
\text { calibration; }\end{array}$ & & $\begin{array}{l}\text { Wulfinghoff, } 1999 \\
\text { Li and Tsang, } 2008 \\
\text { Sachs et al., } 2004 \\
\text { Kómar and Kocifaj, } \\
2014 \\
\text { Martirano et al., } 2014\end{array}$ \\
\hline
\end{tabular}




\begin{tabular}{|c|c|c|c|c|c|c|c|}
\hline & $\begin{array}{l}\text { lighting } \\
\text { purposes }\end{array}$ & $\begin{array}{l}\text { - Reduced } \\
\text { emissions from } \\
\text { reduced energy } \\
\text { flow (e.g. } \\
\text { reduced } \mathrm{CO}_{2} \\
\text { emissions) }\end{array}$ & $\begin{array}{l}\text { - Improved productivity; } \\
\text { - Lower heating } \\
\text { requirements; } \\
\text { - Better mood of the } \\
\text { operators }\end{array}$ & $\begin{array}{l}\text { - Need for reducing the glare's } \\
\text { effect; } \\
\text { - Need for a proper light } \\
\text { control; } \\
\text { - Condensation issues }\end{array}$ & & $\begin{array}{l}\text { - Increased training } \\
\text { of the operators; } \\
\text { - Reduced comfort } \\
\text { for the operators } \\
\text { during installation }\end{array}$ & Shen et al., 2013 \\
\hline $\begin{array}{l}\text { Upgrade } \\
\text { controls on } \\
\text { compressors }\end{array}$ & $\begin{array}{l}\text { Up to } \\
15 \% \text { - } \\
20 \% \text { of } \\
\text { energy } \\
\text { consume } \\
\text { d }\end{array}$ & $\begin{array}{l}\text { - Reduced } \\
\text { energy } \\
\text { expenditures } \\
\text { from the } \\
\text { reduced energy } \\
\text { flow } \\
\text { - Reduced } \\
\text { emissions from } \\
\text { reduced energy } \\
\text { flow (e.g. } \\
\text { reduced } \mathrm{CO}_{2} \\
\text { emissions) }\end{array}$ & $\begin{array}{l}\text { - Lower heating/cooling } \\
\text { requirement; } \\
\text { - Reduced emitted } \\
\text { noise/vibration; } \\
\text { - Reduction of part load } \\
\text { operations; } \\
\text { - Increased reliability of the } \\
\text { equipment; } \\
\text { - Reduced need for cycling of } \\
\text { load/unload; } \\
\text { - Increased equipment life; } \\
\text { - Higher system stability }\end{array}$ & & $\begin{array}{l}\text { - Improved } \\
\text { monitoring of the } \\
\text { system state; } \\
\text { - Possibility to } \\
\text { create a network } \\
\text { of compressors }\end{array}$ & $\begin{array}{l}\text { - Issue in } \\
\text { connecting } \\
\text { compressors of } \\
\text { different firms; } \\
\text { - Interruption of } \\
\text { service supplied }\end{array}$ & $\begin{array}{l}\text { Worrell et al., } 2010 \\
\text { LBNL, 2003 } \\
\text { USDOE, 2002 } \\
\text { Carbon Trust, } 2012 \\
\text { Murphy and Kissock, } \\
2015 \\
\text { Balaras and } \\
\text { Dascalaki, } 2003 \\
\text { Saidur, 2010 }\end{array}$ \\
\hline $\begin{array}{l}\text { Use multiple } \\
\text { speed motors } \\
\text { or adjustable } \\
\text { frequency } \\
\text { drive (afd) for } \\
\text { variable } \\
\text { pump, blower } \\
\text { and } \\
\text { compressors } \\
\text { loads }\end{array}$ & $\begin{array}{l}\text { From } 7 \% \\
\text { to } 60 \% \text { of } \\
\text { the } \\
\text { energy } \\
\text { consumpt } \\
\text { ion }\end{array}$ & $\begin{array}{l}\text { - Reduced } \\
\text { energy } \\
\text { expenditures } \\
\text { from the } \\
\text { reduced energy } \\
\text { flow } \\
\text { - Reduced } \\
\text { emissions from } \\
\text { reduced energy } \\
\text { flow (e.g. } \\
\text { reduced } \mathrm{CO}_{2} \\
\text { emissions) }\end{array}$ & $\begin{array}{l}\text { - Improved productivity; } \\
\text { - Lower heating/cooling } \\
\text { requirements; } \\
\text { - Increased life of equipment; } \\
\text { - Reduced maintenance } \\
\text { costs; } \\
\text { - Increased reliability; } \\
\text { - Reduced cycling with pump } \\
\text { connection; } \\
\text { - Improved product quality; } \\
\text { - Reduced emissions of } \\
\text { noise; } \\
\text { - Increased noise with non- } \\
\text { sinusoidal load; } \\
\text { - Improved process control } \\
\end{array}$ & $\begin{array}{l}\text { - Generation of harmonic } \\
\text { voltage and current distortion; } \\
\text { - Possible radio frequency } \\
\text { interference }\end{array}$ & $\begin{array}{l}\text { - Simplification of } \\
\text { the system; } \\
\text { - Increased } \\
\text { training of the } \\
\text { operators }\end{array}$ & $\begin{array}{l}\text { - Interruption of } \\
\text { service supplied; } \\
\text { - Variation of the } \\
\text { layout }\end{array}$ & $\begin{array}{l}\text { ETSU, } 1998 \\
\text { Worrell et al., } 2010 \\
\text { Ozdemir, } 2004 \\
\text { Saidur, 2010 } \\
\text { Schmehl et al., } 2014 \\
\text { Du Plessis et al., } \\
2013 \\
\text { Shakweh, } 2006\end{array}$ \\
\hline $\begin{array}{l}\text { Size electric } \\
\text { motors for } \\
\text { peak } \\
\text { operating } \\
\text { efficiency }\end{array}$ & $\begin{array}{l}\text { From } 5 \% \\
\text { to } 30 \% \text { of } \\
\text { the } \\
\text { electric } \\
\text { energy } \\
\text { consumpt } \\
\text { ion }\end{array}$ & $\begin{array}{l}\text { - Reduced } \\
\text { energy } \\
\text { expenditures } \\
\text { from the } \\
\text { reduced energy } \\
\text { flow } \\
\text { - Reduced } \\
\text { emissions from } \\
\text { reduced energy } \\
\text { flow (e.g. } \\
\text { reduced } \mathrm{CO}_{2} \\
\text { emissions) }\end{array}$ & $\begin{array}{l}\text { - Longer bearing life; } \\
\text { - Reduced cooling load; } \\
\text { - Reduced heat dissipation; } \\
\text { - Reduced emitted } \\
\text { noise/vibration; } \\
\text { - Reduced part load oper. } \\
\text { issues; } \\
\text { - Higher reliability; } \\
\text { - Improved protection settings }\end{array}$ & $\begin{array}{l}\text { - A direct-on-line starter may } \\
\text { be needed; } \\
\text { - Harder control; } \\
\text { - Need for a proper gearbox }\end{array}$ & $\begin{array}{l}\text { - Monitoring of the } \\
\text { state of the } \\
\text { system }\end{array}$ & $\begin{array}{l}\text { - Interruption of } \\
\text { production; } \\
\text { - Modification to } \\
\text { the layout }\end{array}$ & $\begin{array}{l}\text { ETSU, } 1998 \\
\text { Worrell et al., } 2010 \\
\text { Wulfinghoff, } 1999 \\
\text { Roos et al., } 2006 \\
\text { USDOE, } 2014\end{array}$ \\
\hline
\end{tabular}


Table 5 - Selected companies for exploratory investigation.

\begin{tabular}{|c|c|c|c|c|c|c|}
\hline Company & Sector & \# Employees & Turnover (million $€ /$ year) & Energy Intensity & Energy Manager & Environmental certifications \\
\hline A & C10 - Food & 60 & 15 & $5 \%$ & No & None \\
\hline$B$ & C31 - Furniture & 1,550 & 410 & $2.3 \%$ & Yes & ISO 14001 \\
\hline $\mathrm{C}$ & C24 - Iron and Steel & 515 & 170.65 & $6 \%$ & Yes & ISO 14001 \\
\hline $\mathrm{D}$ & C23 - Glass & 90 & 13 & $10 \%$ & No & ISO 14001 \\
\hline$E$ & C31 - Furniture & 37 & 5.3 & $0.6 \%$ & No & None \\
\hline $\mathrm{F}$ & C28 - Machines & 153 & 32.5 & $0.9 \%$ & No & ISO 14001 \\
\hline G & C27 - Electrical equipment & 116 & 39 & $0.9 \%$ & Yes & ISO 14001 \\
\hline
\end{tabular}


Table 6 - Main evidence and comments from sampled companies.

Legend: $\quad \checkmark \checkmark=$ the performance has been fully positively evaluated without any further comment. $=$ the performance has been positively evaluated, further suggestions are offered. $x=$ the performance has been negatively evaluated.

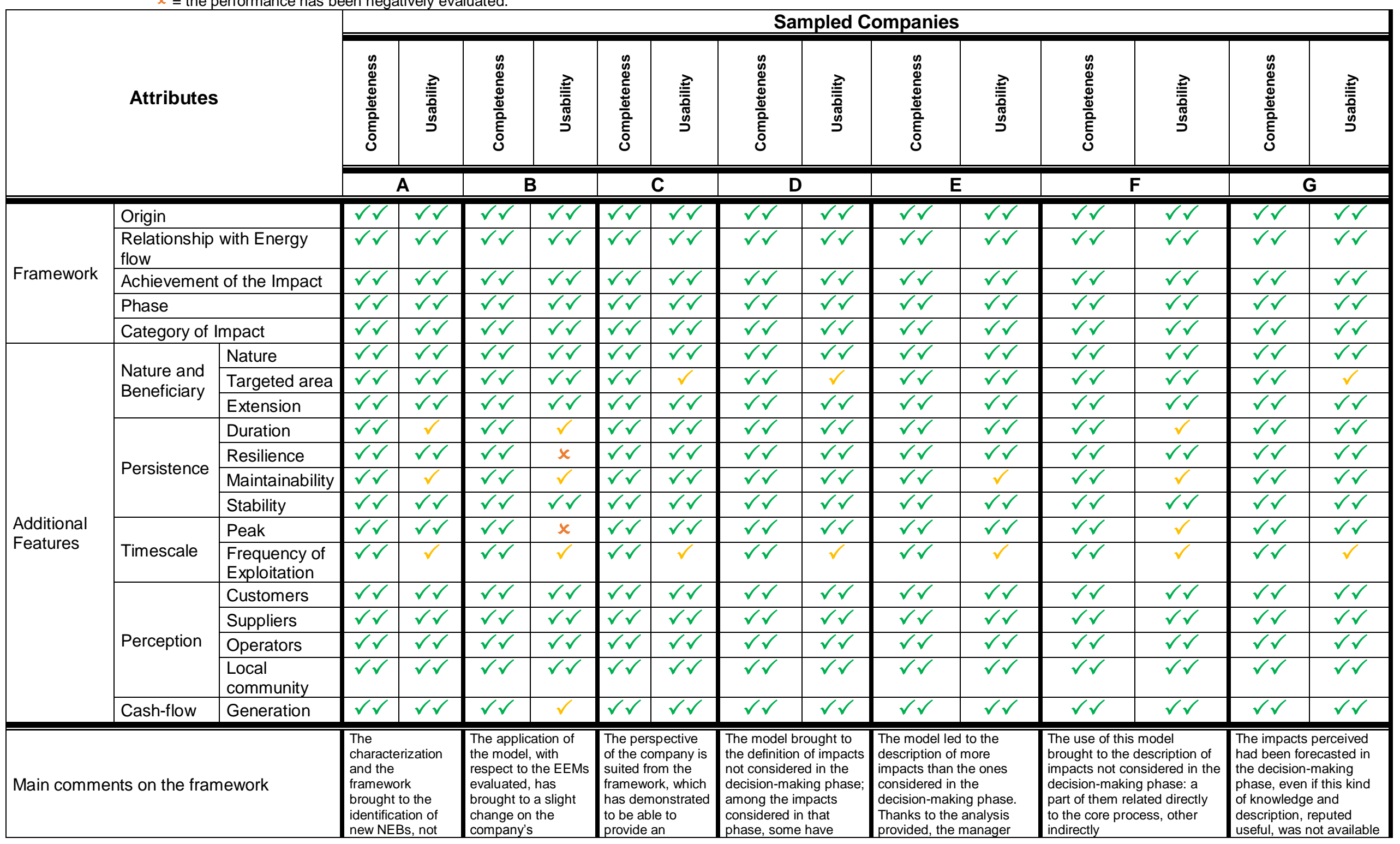




\begin{tabular}{|c|c|c|c|c|c|c|c|}
\hline & \begin{tabular}{|l} 
taken into \\
account in the \\
decision-making \\
phase; attention \\
towards the \\
external impacts \\
through a \\
structured \\
description of the \\
EEMs \\
\end{tabular} & $\begin{array}{l}\text { perspective: impacts } \\
\text { on the production or } \\
\text { work environment } \\
\text { were unexpected; } \\
\text { identification of } \\
\text { impacts (losses) not } \\
\text { considered in the } \\
\text { decision-making } \\
\text { phase }\end{array}$ & $\begin{array}{l}\text { indication of those } \\
\text { impacts of interest } \\
\text { for the } \\
\text { management }\end{array}$ & $\begin{array}{l}\text { been wrongly } \\
\text { forecasted, as } \\
\text { presented later on }\end{array}$ & $\begin{array}{l}\text { has pointed out that } \\
\text { further investments would } \\
\text { be accomplished for the } \\
\text { adoption of skylights }\end{array}$ & & $\begin{array}{l}\text { at that time. It has been } \\
\text { positively judged the } \\
\text { attributes of the } \\
\text { characterization, } \\
\text { especially the phase in } \\
\text { which the benefits arise }\end{array}$ \\
\hline Further suggestions for specific attributes & $\begin{array}{l}\text { Manager } \\
\text { proposed a } \\
\text { change in the } \\
\text { evaluation scales } \\
\text { for the duration of } \\
\text { the impact and } \\
\text { the frequency of } \\
\text { exploitation }\end{array}$ & $\begin{array}{l}\text { Proposed new } \\
\text { evaluation scales for } \\
\text { the duration of the } \\
\text { impact and the } \\
\text { frequency of } \\
\text { exploitation; } \\
\text { proposed an overall } \\
\text { evaluation of the } \\
\text { maintainability; not } \\
\text { interested in the } \\
\text { resilience; proposed } \\
\text { effects of the impact } \\
\text { on PBT instead of } \\
\text { the peak of the } \\
\text { impacts itself }\end{array}$ & $\begin{array}{l}\text { Added some } \\
\text { options in the } \\
\text { evaluation scales; } \\
\text { proposed a } \\
\text { change in the } \\
\text { evaluation scale } \\
\text { for the frequency } \\
\text { of exploitation }\end{array}$ & $\begin{array}{l}\text { Proposed a change in } \\
\text { the evaluation of the } \\
\text { frequency of } \\
\text { exploitation; proposed } \\
\text { a change for some } \\
\text { options among the } \\
\text { available ones; poor } \\
\text { knowledge about } \\
\text { resilience }\end{array}$ & $\begin{array}{l}\text { Proposed a change in the } \\
\text { evaluation scale for the } \\
\text { frequency of exploitation; } \\
\text { overall evaluation for the } \\
\text { maintenance (not } \\
\text { considering the indexes); } \\
\text { poor knowledge about } \\
\text { resilience }\end{array}$ & $\begin{array}{l}\text { Not considered the resilience } \\
\text { of the benefit; no } \\
\text { consideration for the } \\
\text { ergonomics; proposed a } \\
\text { change in the evaluation } \\
\text { scale for the frequency of } \\
\text { exploitation }\end{array}$ & $\begin{array}{l}\text { Proposed a change in } \\
\text { the evaluation scale for } \\
\text { the frequency of } \\
\text { exploitation; proposed } \\
\text { change in some of the } \\
\text { evaluation scales, } \\
\text { reducing the number of } \\
\text { choices available; poor } \\
\text { knowledge about } \\
\text { resilience }\end{array}$ \\
\hline
\end{tabular}

